\title{
8. PLANKTONIC FORAMINIFER CENOZOIC BIOSTRATIGRAPHY OF THE ARCTIC OCEAN, FRAM STRAIT (SITES 908-909), YERMAK PLATEAU (SITES 910-912), AND EAST GREENLAND MARGIN (SITE 913) ${ }^{1}$
}

\author{
Dorothee Spiegler ${ }^{2}$
}

\begin{abstract}
The resolution of a planktonic foraminifer Cenozoic biostratigraphy in the Greenland Sea and in the Arctic Ocean is quite low, because of the scarcity of calcareous microfossils and the low diversity of assemblages. The Neogloboquadrina pachyderma sin. Zone spans the entire Quaternary, whereas the Neogloboquadrina atlantica Superzone occupies the Pliocene and parts of the upper Miocene. Biogenic ice-rafted debris such as Inoceramus-prisms, indicative of glacial conditions, are first documented during the late Pliocene at the Fram Strait sites and at the Yermak Plateau. Conversely, brief warm-temperate to subtropical surface-water ingressions, documented by the occurrence of single specimens of Menardella menardii, M. limbata, Globigerinoides ruber, Gls. conglobatus, Gls. extremus, Gls. trilobus, Globigerinella aequilateralis, Sphaeroidinellopsis sp. juv., aff. S. paenedehiscens, and Dentoglobigerina altispira are observed locally at the Yermak Plateau in the upper Pliocene sequence. Surface-water exchange to the north is documented by the occurrence of the Pacific planktonic foraminifer Neogloboquadrina asanoi in upper Pliocene sediments at the Fram Strait. Rare occurrences of planktonic foraminifers in Miocene and Paleogene sediments prevent the construction of a zonation.
\end{abstract}

\section{INTRODUCTION}

Seven sites (Sites 907-913) were drilled during Ocean Drilling Program (ODP) Leg 151. The sites were located in four regions to investigate the paleoceanography and paleoclimatology of the northern high latitudes (Fig. 1). A north-south transect was drilled involving Sites 908 through 912 . Site 911 with three holes drilled (between $80^{\circ} 28.466^{\prime} \mathrm{N}-80^{\circ} 28.485^{\prime} \mathrm{N}$ and $\left.8^{\circ} 13.636^{\prime} \mathrm{E}-8^{\circ} 13.640^{\prime} \mathrm{E}\right)$ is the most northerly site. Site 908 with Hole $908 \mathrm{~A}\left(78^{\circ} 23.112^{\prime} \mathrm{N} ; 1^{\circ} 21.637^{\prime} \mathrm{E}\right)$ and Hole $908 \mathrm{~B}\left(78^{\circ} 23.125^{\prime} \mathrm{N} ; 1^{\circ} 21.644^{\prime} \mathrm{E}\right)$ is the most southerly tie point in this transect. The study of planktonic foraminifers encountered in the sediments at these five sites is the main objective of this paper. The biostratigraphy of Site 913 , drilled in the Greenland Basin, is also studied by means of planktonic foraminifers. Site 907 , drilled on the eastern Iceland Plateau, is not considered in this study.

Generally, at the northern high latitudes most of the samples are poor in planktonic foraminifers or barren, owing to cold-water temperatures and/or dissolution of the calcareous microfossils. Another factor is dilution by high amounts of detrital material and ice-rafted debris (IRD).

The high-latitude planktonic foraminifer associations are low diversity faunas composed of long-ranging species. The standard zonations established for low latitudes (Blow, 1969, 1979; Bolli and Saunders, 1985), and for northern temperate regions (Berggren, 1972; Poore and Berggren, 1975; Poore, 1979; and Weaver and Clement, 1986) are generally not applicable because the index fossils used for these zonal definitions are often absent in high latitudes. Only in a few short Neogene intervals at the investigated sites do single observations of immigrant warm-adapted species of planktonic foraminifers allow a rough correlation to the above-mentioned zonations. Studies of the Leg 104 sites in the Norwegian Sea have pro-

'Thiede, J., Myhre, A.M.. Firth, J.V., Johnson, G.L., and Ruddiman, W.F. (Eds.), 1996. Proc. ODP, Sci. Results, 151: College Station, TX (Ocean Drilling Program).

${ }^{2}$ GEOMAR, Research Center for Marine Geosciences, Wischhofstraße 1-3, D24148 Kiel, Federal Republic of Germany. dspiegler@geomar.de duced a local high-latitude Neogene zonation (Spiegler and Jansen, 1989), which is more useful for the interpretation of the Leg 151 data.

\section{METHODS}

Stratigraphic results and paleotemperature estimations for Leg 151 were obtained by the investigation of planktonic foraminifers from about 1400 samples. Samples were taken from the core catchers and from the calcareous sediments. About one $20-\mathrm{cm}^{3}$ sample per section of core was used. The preparation methods used to obtain foraminifers differed depending on the degree of sediment induration. Soft sediments were washed over a $63-\mu \mathrm{m}$ screen. Slightly indurated sediments were soaked in diluted $\mathrm{H}_{2} \mathrm{O}_{2}$ solution and then wet sieved. Indurated samples were freeze-dried, soaked in hot paraffin, and boiled in a soda lye solution until disintegration occurred. This method was repeated until a reasonable amount of loose particles was obtained. Range tables summarize the main characteristics used for planktonic foraminiferal studies (Tables 1-11).

\section{PLANKTONIC FORAMINIFER BIOSTRATIGRAPHY}

The Neogloboquadrina pachyderma sin. Zone spans the entire Quaternary. The nearly monospecific association of $N$. pachyderma sin. shows highly variable abundances, ranging from several periods containing a hundred thousand specimens in $10-\mathrm{cm}^{3}$ sediment to intervals barren of planktonic foraminifers (Myhre, Thiede, Firth, et al., 1995). Such alternations seem to be typical of the changes between glacials and interglacial conditions, as absolute abundances of planktonic foraminifers correlate best with surface seawater temperatures calculated from oxygen isotopes (Paul, 1992).

The Neogloboquadrina atlantica Superzone is defined by the range of the zonal marker, spanning the whole Pliocene and reaching into the late Miocene. Using the change in coiling direction, local zones are defined (Weaver and Clement, 1986; Spiegler and Jansen, 1989). The last occurrence of $N$. atlantica marks the Quaternary/ Pliocene boundary, whereas the Pliocene/Miocene boundary cannot be defined in high latitudes by planktonic foraminifers. 


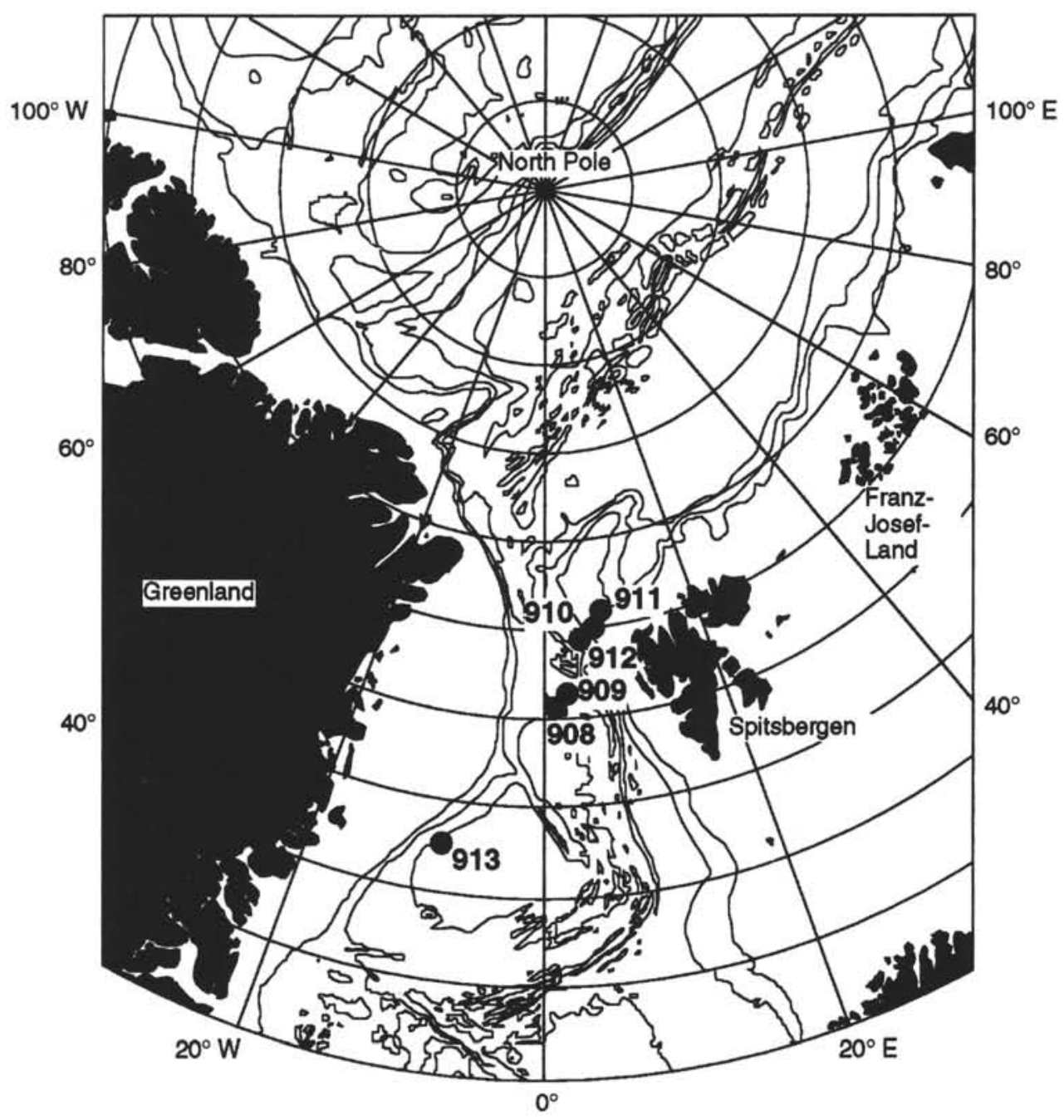

Figure 1. Location map of Sites 908 through 913.

The Miocene and Eocene sediments in the area of investigation contain only some spot observations of planktonic foraminifers. No planktonic foraminifers were found in Oligocene sediments.

\section{YERMAK PLATEAU}

The Yermak Plateau extends for about $400 \mathrm{~km}$ in a north-northwest direction from the shelf of Svalbard into the Arctic Ocean. The area is well suited for paleoceanographic analysis of Pliocene/Quaternary glacial/interglacials and the preglacial conditions. A northsouth transect was drilled across the plateau with Site 911 in the north, Site 912 in the south, and Site 910 between.

\section{Site 911}

Site 911 was the most northerly site drilled during Leg 151 and is located on the southeastern part of the Yermak Plateau, $35 \mathrm{~km}$ eastnortheast of Site 910. It was drilled in about $900-\mathrm{m}$ water depth on the upper slope toward the Nansen Basin, at approximately $80^{\circ} 28.5^{\prime} \mathrm{N}, 8^{\circ} 13.6^{\prime} \mathrm{E}$. The biostratigraphic results obtained by the investigation of planktonic foraminifers are based on Hole $911 \mathrm{~A}$ (Table 1). Down to 505 meters below seafloor (mbsf), 342 samples (one per section) were analyzed. Planktonic foraminifers occurred in the Qua- ternary section in $62 \%$ of the samples, and foraminifers are rare in the Pliocene sequences, where only $23 \%$ of the samples contained planktonic foraminifers. Hole $911 \mathrm{~A}$ reached Miocene sediments.

The Quaternary/Pliocene boundary is defined by the last observation of Neogloboquadrina atlantica in dextral coiling direction in Sample 151-911A-25X-1, 112-115 cm (227.52 mbsf), which is situated just above the paleomagnetic Chron $\mathrm{C} 2 \mathrm{n}$, the Olduvai Event (Myhre, Thiede, Firth, et al., 1995), at approximately 1.7 Ma.

In the 228-m-thick Quaternary sequence the associations of planktonic foraminifers of low diversity show highly variable abundances. Such alternations seem to be typical of the changes between glacial and cold (interglacial) conditions. The assemblages consist mainly of Neogloboquadrina and Globigerina taxa, dominated by the polar $N$. pachyderma $\sin$. Ice-rafted Cretaceous Inoceramus-prisms are found in the sediments between 35.66 and $47.50 \mathrm{mbsf}$, at 114.03 mbsf, from 128.30 to $129.80 \mathrm{mbsf}$, and at 171.25 mbsf. Rare occurrence of temperate-adapted Orbulina universa, Globoconella inflata, and Globorotalia scitula in the sequence from 144.06 to $145.56 \mathrm{mbsf}$ and a single observation of Globigerinoides ruber at $194.95 \mathrm{mbsf}$ document the fact that temperate to warm surface water sporadically reached into high latitudes. The single presence of these indices may be related to short warmer episodes, not long enough to produce rich and well-diversified assemblages. Therefore, at Site 911 the whole Quaternary may be characterized generally as cold. A sequence of 
Table 1. Distribution of planktonic foraminifers in Hole 911A.

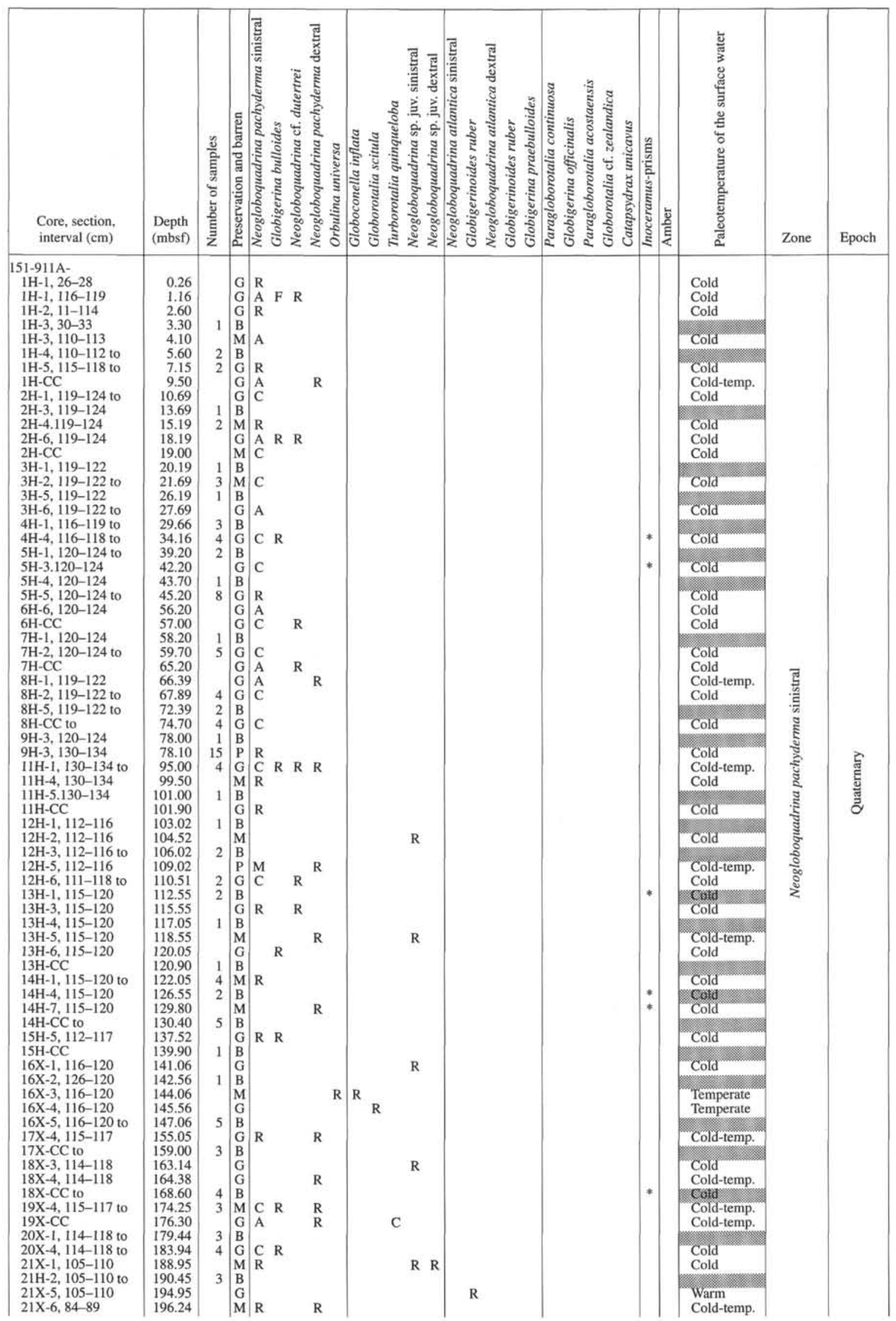


Table 1 (continued).

\begin{tabular}{|c|c|c|c|c|c|c|c|c|c|c|c|c|c|}
\hline $\begin{array}{l}\text { Core, section, } \\
\text { interval }(\mathrm{cm})\end{array}$ & $\begin{array}{l}\text { Depth } \\
\text { (mbsf) }\end{array}$ & 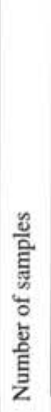 & 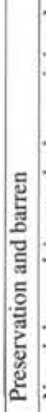 & 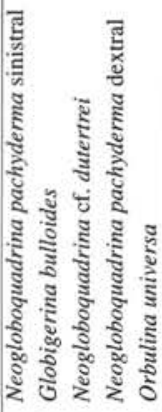 & 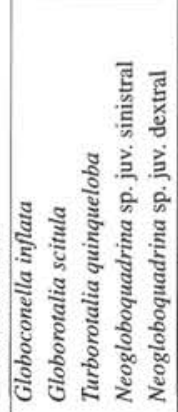 & 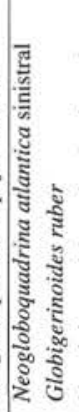 & 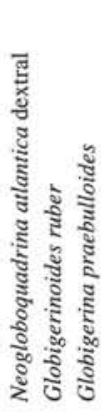 & 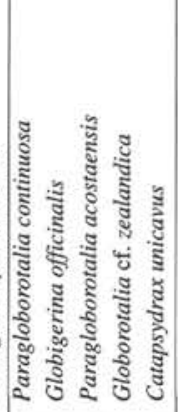 & 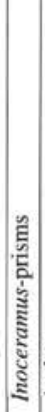 & 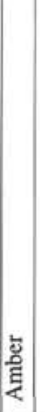 & 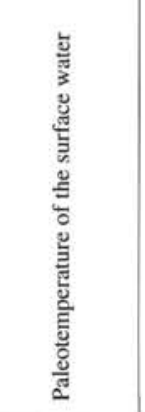 & Zone & Epoch \\
\hline $\begin{array}{l}21 \mathrm{X}-\mathrm{CC} \\
22 \mathrm{X}-1,113-117 \text { to } \\
22 \mathrm{X}-3,116-120 \text { to } \\
23 \mathrm{X}-2,223-227 \text { to } \\
24 \mathrm{X}-3,115-119 \\
24 \mathrm{X}-6,115-119 \text { to }\end{array}$ & $\begin{array}{l}197.50 \\
198.63 \\
201.59 \\
208.33 \\
219.85 \\
223.39 \\
\end{array}$ & $\begin{array}{l}2 \\
5 \\
7 \\
4\end{array}$ & \begin{tabular}{|c|}
$\mathrm{M}$ \\
$\mathrm{B}$ \\
$\mathrm{M}$ \\
$\mathrm{B}$ \\
$\mathrm{M}$ \\
$\mathrm{B}$
\end{tabular} & $\begin{array}{lll}R & R \\
R & R & \\
R & & \end{array}$ & $R$ & & & & & & $\begin{array}{l}\text { Cold-temp. } \\
\text { Cold } \\
\text { Cold }\end{array}$ & & \\
\hline $25 \mathrm{X}-1,112-115$ & 227.52 & & $\mathrm{P}$ & & & $\mathrm{R}$ & $\mathrm{R}$ & & & & Warm-temp. & $\# 1$ & $\# 2$ \\
\hline $\begin{array}{l}25 X-2,112-15 \\
25 X-3,112-115 \text { to } \\
27 X-1,113-118 \\
27 X-2,113-118 \\
27 X-3,113-118 \\
27 X-5,113-118 \text { to } \\
28 X-2,113-118 \\
28 X-3,109-115 \text { to } \\
28 X-6,114-119 \\
28 X-7,1-3 \text { to } \\
28 X-C C \\
29 X-2,110-113 \text { to } \\
30 X-5,98-101 \\
30 X-C C \text { to } \\
31 X-4,116-120 \\
31 X-5,120-122 \\
31 X-6,120-122 \\
31 X-C C \text { to } \\
32 X-3,115-120 \\
32 X-4,117-122 \text { to } \\
33 X-4,115-119 \\
33 X-C C \text { to } \\
34 X-2,113-117 \\
34 X-3,113-117 \\
34 X-4,113-117 \\
34 X-5,113-117 \text { to } \\
34 X-C C \\
35 X-1,114-117 \text { to } \\
36 X-3,115-119 \text { to } \\
47 X-6,121-125 \text { to } \\
50 X-2,115-119 \\
50 X-3,115-119 \text { to } \\
51 X-C C\end{array}$ & $\begin{array}{l}229.02 \\
230.52 \\
246.93 \\
248.43 \\
249.93 \\
251.61 \\
258.13 \\
259.59 \\
264.14 \\
264.51 \\
265.10 \\
267.23 \\
281.58 \\
284.30 \\
289.96 \\
291.50 \\
293.00 \\
294.00 \\
298.15 \\
299.67 \\
309.25 \\
313.30 \\
315.93 \\
317.43 \\
318.93 \\
320.25 \\
322.90 \\
324.04 \\
336.71 \\
446.27 \\
469.85 \\
471.35 \\
486.50\end{array}$ & $\begin{array}{r}8 \\
1 \\
3 \\
3 \\
2 \\
10 \\
4 \\
1 \\
3 \\
6 \\
2 \\
\\
2 \\
8 \\
69 \\
15 \\
11\end{array}$ & \begin{tabular}{|l|}
$\mathrm{G}$ \\
$\mathrm{B}$ \\
$\mathrm{G}$ \\
$\mathrm{B}$ \\
$\mathrm{M}$ \\
$\mathrm{B}$ \\
$\mathrm{M}$ \\
$\mathrm{B}$ \\
$\mathrm{M}$ \\
$\mathrm{B}$ \\
$\mathrm{M}$ \\
$\mathrm{B}$ \\
$\mathrm{P}$ \\
$\mathrm{B}$ \\
$\mathrm{G}$ \\
$\mathrm{B}$ \\
$\mathrm{G}$ \\
$\mathrm{B}$ \\
$\mathrm{G}$ \\
$\mathrm{B}$ \\
$\mathrm{M}$ \\
$\mathrm{B}$ \\
$\mathrm{G}$ \\
$\mathrm{B}$ \\
$\mathrm{P}$ \\
$\mathrm{B}$ \\
$\mathrm{G}$ \\
$\mathrm{B}$ \\
$\mathrm{M}$ \\
$\mathrm{B}$ \\
$\mathrm{P}$ \\
$\mathrm{B}$ \\
$\mathrm{M}$
\end{tabular} & $\begin{array}{l}R \\
R\end{array}$ & R R & $\begin{array}{l}\mathrm{R} \\
\mathrm{R} \\
\mathrm{R}\end{array}$ & $\begin{array}{ll}\mathrm{R} & \\
\mathrm{R} & \\
& \\
& \mathrm{R} \\
\mathrm{R} & \mathrm{R} \\
& \mathrm{R} \\
\mathrm{R} & \\
& \\
\mathrm{R} & \\
& \mathrm{R} \\
& \end{array}$ & & $*$ & $\begin{array}{l}\mathrm{R} \\
\mathrm{R} \\
\mathrm{R} \\
\mathrm{R}\end{array}$ & 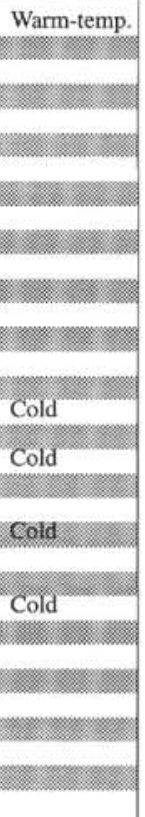 & 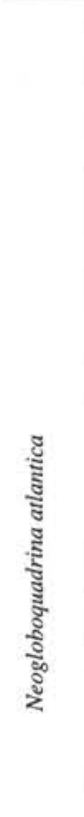 & 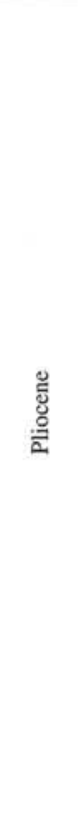 \\
\hline $\begin{array}{l}52 X-2,115-119 \\
52 X-3,115-119 \\
52 X-4,115-119 \\
52 X-6,115-119 \text { to } \\
53 X-2,113-117 \\
53 X-3,33-38 \\
53 X-3,113-117 \\
53 X-4,33-38 \\
53 X-4,113-117 \\
53 X-5,62-67 \\
53 X-5,84-89 \\
53 X-5,111-113\end{array}$ & $\begin{array}{l}488.40 \\
489.90 \\
491.40 \\
493.99 \\
498.07 \\
498.73 \\
499.57 \\
500.74 \\
501.07 \\
502.08 \\
502.28 \\
502.29\end{array}$ & 3 & $\begin{array}{l}\mathrm{M} \\
\mathrm{M} \\
\mathrm{M} \\
\mathrm{B} \\
\mathrm{G} \\
\mathrm{B} \\
\mathrm{G} \\
\mathrm{B} \\
\mathrm{P} \\
\mathrm{B} \\
\mathrm{P} \\
\mathrm{P}\end{array}$ & & $R$ & $\begin{array}{l}\text { C } \\
\text { R }\end{array}$ & $\begin{array}{l}\mathrm{C} \\
\mathrm{R} \\
\end{array}$ & R & & & & & 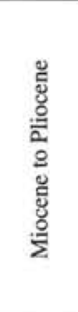 \\
\hline $\begin{array}{l}53 X-5,113-117 \\
53 X-6,31-36 \\
53 X-6,113-117 \text { to } \\
53 X-C C\end{array}$ & $\begin{array}{l}502.31 \\
502.86 \\
503.68 \\
505.80\end{array}$ & 2 & \begin{tabular}{l|}
$\mathrm{M}$ \\
$\mathrm{M}$ \\
$\mathrm{B}$ \\
$\mathrm{B}$
\end{tabular} & $\mathrm{R}$ & R & & C & \begin{tabular}{|lllll}
$R$ & $R$ & $R$ & $R$ & $R$ \\
& $R$ & &
\end{tabular} & & & Warm & & \\
\hline
\end{tabular}

Notes: The state of preservation of the planktonic foraminifers is described as $\mathrm{G}=$ good (little or no fragmentation, overgrowth, and/or dissolution), $\mathrm{M}=\mathrm{moderate}$ (some signs of fragmentation, overgrowth, and/or dissolution), and $\mathrm{P}=$ poor (severe fragmentation, heavy overgrowth, and/or dissolution). The abundances are categorized as $\mathrm{A}=$ abundant (more than 25 specimens), $\mathrm{C}=$ common ( $5-24$ specimens), and $\mathrm{R}=$ rare (less than 5 specimens). Barren (B) sequences are marked with a stipled signature. \#1 = upper Neogloboquadrina atlantica dextral, \#2 = upper Pliocene. 
$7.55 \mathrm{~m}$ barren of planktonic foraminifers separated the fossiliferous Quaternary and the Pliocene, containing foraminifers.

The Pliocene sediments of Hole 911A are extremely poor in planktonic foraminifers. Large parts of the sequence are almost barren or contained no age diagnostic planktonic foraminifers. Because of these difficulties, a clear subdivision of the 275-m-thick Pliocene sequence is impossible. The uppermost sample of the Pliocene sequence, Sample 151-911A-25X-1, 112-115 cm, contains Globigerinoides ruber and Neogloboquadrina atlantica dextral. The latter species is indicative of the Neogloboquadrina atlantica dextral Zone of the latest Pliocene (Spiegler and Jansen, 1989). Down to 318.93 mbsf (Sample 151-911A-34X-4, 113-117 cm), only a few samples yielded $N$. atlantica in its sinistral or dextral coiling mode. These rare occurrences do not allow the distinguishing of zones by coiling direction. Spheres of amber indicate reworking down to $365.44 \mathrm{mbsf}$, and ice-rafted Inoceramus-prisms down to 318.93 mbsf document glacial conditions back into the late Pliocene. The sediments below 318.93 mbsf down to 335.23 mbsf contain no age diagnostic fossils. From Sample 151-911A-36X-3, $115-119 \mathrm{~cm}$, at $336.71 \mathrm{mbsf}$, down to Sample 151-911A-53X-5, 111-113 cm, at 502.29 mbsf, the sediments contain N. atlantica sin., which is indicative of the Neogloboquadrina atlantica $\sin$. Zone, spanning Pliocene to latest Miocene (Spiegler and Jansen, 1989). The last observations of Globigerina praebulloides in Sample 151-911A-52X-2, 115-119 cm, at 488.40 mbsf, and a single specimen of Paragloborotalia continuosa in Sample 151-911A-52X-4, 115-119 cm, at $491.40 \mathrm{mbsf}$, indicate Pliocene to Miocene age. On the Vøring Plateau the LO (last occurrence) of $P$. continuosa is not younger than 4.7 Ma (Spiegler and Jansen, 1989). Miocene is confirmed in Sample 151-911A-53X-5, 113-117 cm, at 502.31 mbsf, by the co-occurrence of N. pachyderma dextral, Globigerina praebulloides, $G$. officinalis, Globorotalia cf. zealandica, Catapsydrax unicavus, Paragloborotalia continuosa, and P. acostaensis. According to Kennett and Srinivasan (1980 and 1983), $P$. continuosa intergrades with $N$. pachyderma in late Miocene to early Pliocene in temperate to polar regions. The last $3 \mathrm{~m}$ of the cored sediment are barren in planktonic foraminifers.

\section{Site 910}

Site 910 is located on the summit of the central inner Yermak Plateau and is the shallowest site of the drilled transect. Holes 910A$910 \mathrm{D}$ were drilled in $556 \mathrm{~m}$ water depth at approximately $80^{\circ} 15.8^{\prime} \mathrm{N}$, $6^{\circ} 35.4^{\prime} \mathrm{E}$. The biostratigraphic results are largely based on Hole 910C (Table 2) and were completed with the results of Hole 910D (Table 3). Holes 910A and 910B stopped in Quaternary sediments, reaching only 34.0 mbsf and $15.6 \mathrm{mbsf}$, respectively. We analyzed $191 \mathrm{sam}-$ ples from Hole 910C (down to $507 \mathrm{mbsf}$ ) and 58 samples from Hole 910D (5.80 through $156.30 \mathrm{mbsf}$ ). Planktonic foraminifers occurred in $63 \%$ of the samples from Hole $910 \mathrm{C}$ and in $38 \%$ of the samples from Hole 910D. All 25 analyzed samples from Hole 910A (Table 4) contain abundant and well-preserved planktonic foraminifers of Quaternary age.

Nearly monospecific associations of the polar N. pachyderma sin. characterize the upper part of the Quaternary sequence. The assemblages also sporadically contain specimens of $N$. pachyderma in its dextral coiling mode, the five-chambered $N$. cf. dutertrei, and small Globigerina $\mathrm{cf}$. bulloides. Below $35.30 \mathrm{mbsf}$, the lower sequence of the Quaternary in Holes 910C and 910D is extremely poor or barren of planktonic foraminifers. Ice-rafted Inoceramus-prisms are found at several levels in the Quaternary. Consequently, during the whole Quaternary, the surface-water masses at Site 910 may be characterized as cold.

The Quaternary/Pliocene boundary is well documented in Core 151-910D-10X: the base of the N. pachyderma sin. Zone (Quaternary) lies in Sample 151-910D-10X-2, 75-77 cm, at $76.35 \mathrm{mbsf}$, and Pliocene is documented in Sample 151-910D-10X-3, 74-76 cm, at
77.84 mbsf by a small ( $350 \mu \mathrm{m}$ in diameter) juvenile or immature Sphaeroidinellopsis sp., aff. S. paenedehiscens (Blow). Bolli and Saunders (1985) placed $S$. paenedehiscens within the $S$. seminulina plexus. Weaver and Clement (1986) dated the LO of S. seminulina with $3 \mathrm{Ma}$. Therefore, if the observed specimen of Sphaeroidinellopsis $\mathrm{sp}$. is not reworked, parts of the upper Pliocene may be missing. The planktonic foraminifer Zone N21 (Blow) can be determined in the Samples 151-910D-10X-3, 74-76 cm, 151-910D-15X-3, 74-76 $\mathrm{cm}$, and 151-910D-16X-2, 74-76 cm. The co-occurrence of Menardella limbata (N12 to Recent), Dentoglobigerina altispira (N4B to N21, LO $2.95 \mathrm{Ma}$ ), Globorotalia dutertrei, which starts in N21, and Globigerinoides extremus (N16 to N21) is indicative. Below 153 mbsf in Hole 910D, down to 504 mbsf in Hole 910C, the entire sequence is assigned to the Neogloboquadrina atlantica sinistral Zone of the Pliocene. Further stratigraphic subdivision is impossible because of the scarcity of the assemblages. Ice-rafted Inoceramusprisms are documented down to 178.9 mbsf (Sample 151-910C-19RCC).

The spot observations of the above-mentioned subtropical to warm-temperate planktonic foraminifers are indicative for several short, distinct, warm to subtropical surface-water ingressions during the generally cold late Pliocene. The topmost Pliocene sequence at Site 910 (Samples 151-910D-10X-3, 74-76 cm, and 10X-CC) contains assemblages with $N$. pachyderma dextral, Sphaeroidinellopsis sp., Globigerinoides trilobus, and Turborotalita quinqueloba, indicating warm surface water. The downhole $41 \mathrm{~m}$ of sediment (down to 124.74 mbsf in Hole 910D) is barren of planktonic foraminifers, except Samples 151-910D-13X-2, 74-76 cm, and 14X-2, 74-76 cm, which contain Globigerinella aequilateralis. The latter species also characterize temperate surface-water masses. The most distinct warm-water assemblages are documented in Samples 151-910D$15 \mathrm{X}-2,74-76 \mathrm{~cm}, 16 \mathrm{X}-2,74-76 \mathrm{~cm}, 16 \mathrm{X}-3,74-76 \mathrm{~cm}$, and $16 \mathrm{X}-3$, $74-76 \mathrm{~cm}$. Menardella menardii, M. limbata, Neogloboquadrina dutertrei, Dentoglobigerina altispira, Globogerinoides ruber, Gls. conglobatus, Gls. extremus, and Gls. trilobus indicate subtropical surface-water temperatures. These warm intervals lie in a sequence mainly barren of planktonic foraminifers that contains ice-rafted Inoceramus-prisms and assemblages of cold-adapted benthic foraminifers. Therefore, the climatic scenario in the area of investigation may be interpreted as containing episodic ingressions of warm and subtropical surface-water masses into a generally cold ocean during the late Pliocene. The cold conditions of the late Pliocene are further documented by $N$. pachyderma $\sin$. in Cores 151-910D-17X and 18X. In Sample 151-910D-18X-2, 74-76 cm, N. pachyderma sin. occurs together with $N$. atlantica sin., indicative of northern high latitude Pliocene and late Miocene (Spiegler and Jansen, 1989).

\section{Site 912}

Site 912 is located on the southwestern part of the Yermak Plateau, $45 \mathrm{~km}$ southwest of Site 910 . Three holes were drilled on the slope toward the Molloy Rift and the Spitsbergen Fracture Zone in about $1037 \mathrm{~m}$ water depth at approximately $79^{\circ} 57.5^{\prime} \mathrm{N}, 5^{\circ} 27.4^{\prime} \mathrm{E}$. All holes had to be abandoned because of advancing ice. Hole $912 \mathrm{~A}$ penetrated $145.4 \mathrm{~m}$ of sediment, reaching the top of the Pliocene sequence. Hole 912B drilled only $40.5 \mathrm{~m}$ into Quaternary sediments, and Hole 912C was stopped at $209.1 \mathrm{mbsf}$ in the Pliocene sequence.

Planktonic foraminifer biostratigraphy of Site 912 is based on the examination of all core-catcher samples from Hole 912A (Samples 151-912A-1H-CC through 15X-CC; Table 5), Hole 912B (Samples 151-912B-1H-CC through 5H-CC; Table 6), and Hole 912C (Samples 151-912C-1R-CC through 12R-CC; Table 7). Six additional samples were analyzed from Cores 151-912A-15X to study the Quaternary/Pliocene boundary and three samples from Core 151-912C$12 \mathrm{X}$ to examine the fossil content of the Neogloboquadrina atlantica $\sin$. Zone. 
Table 2. Distribution of planktonic foraminifers in Hole 910C.

\begin{tabular}{|c|c|c|c|c|c|c|c|c|c|c|c|}
\hline $\begin{array}{l}\text { Core, section, } \\
\text { interval }(\mathrm{cm})\end{array}$ & $\begin{array}{l}\text { Depth } \\
\text { (mbsf) }\end{array}$ & 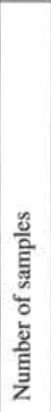 & 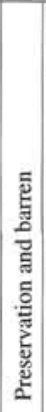 & 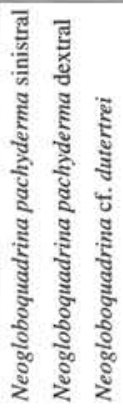 & 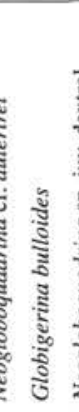 & 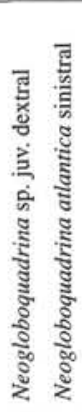 & 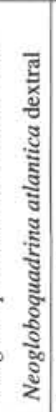 & 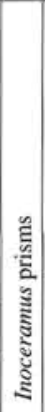 & 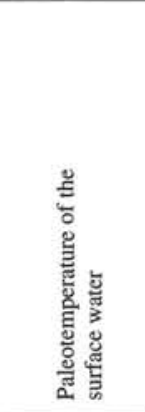 & Zone & Epoch \\
\hline $\begin{array}{l}151-910 \mathrm{C}- \\
1 \mathrm{R}-1,0-3 \\
\text { IR-1,64 to } \\
2 \mathrm{R}-1,68-73 \\
2 \mathrm{R}-\mathrm{CC} \text { to } \\
5 \mathrm{R}-2,38-42 \\
\text { 5R-CC } \\
\text { 6R-CC } \\
7 \mathrm{R}-\mathrm{CC}\end{array}$ & $\begin{array}{r}0.00 \\
0.64 \\
9.18 \\
17.40 \\
37.18 \\
44.90 \\
54.50 \\
64.20\end{array}$ & $\begin{array}{r}1 \\
4 \\
10\end{array}$ & $\begin{array}{l}\mathrm{B} \\
\mathrm{G} \\
\mathrm{G} \\
\mathrm{M} \\
\mathrm{M} \\
\mathrm{B} \\
\mathrm{G} \\
\mathrm{G}\end{array}$ & $\begin{array}{lll}C & \mathrm{R} & \mathrm{R} \\
\mathrm{C} & \mathrm{R} & \\
\mathrm{R} & & \\
\mathrm{R} & & \\
& & \\
\mathrm{R} & & \\
\mathrm{R} & & \end{array}$ & $R$ & & & $*$ & $\begin{array}{l}\text { Cold } \\
\text { Cold } \\
\text { Cold } \\
\text { Cold } \\
\text { Cold } \\
\text { Cold }\end{array}$ & $\begin{array}{l}\frac{5}{n} \\
\text { हैं } \\
\Xi \\
\Sigma \\
z\end{array}$ & हुّ \\
\hline $\begin{array}{l}8 \mathrm{R}-\mathrm{CC} \\
9 \mathrm{R}-\mathrm{CC} \text { to } \\
10 \mathrm{R}-\mathrm{CC} \\
11 \mathrm{R}-\mathrm{CC} \\
12 \mathrm{R}-\mathrm{CC} \text { to } \\
16 \mathrm{R}-\mathrm{CC}\end{array}$ & $\begin{array}{r}73.80 \\
83.40 \\
93.10 \\
102.80 \\
112.40 \\
150.90\end{array}$ & 4 & $\begin{array}{c}\mathrm{B} \\
1 \\
1 \\
\mathrm{G} \\
\mathrm{B} \\
\mathrm{B}\end{array}$ & & & $\mathrm{R}$ & & & No recovers: & & \\
\hline $\begin{array}{l}17 R-1,99-103 \text { to } \\
20 R-1,69-72 \text { to } \\
20 R-5,69-72 \\
20 R-C C \\
21 R-1,42-44 \\
21 R-C C \\
22 R-1,99-103 \\
22 R-2,100-103 \text { to } \\
23 R-4,97-102 \\
23 R-5,97-102 \\
23 R-C C \\
24 R-1,82-85 \text { to } \\
25 R-C C \text { to } \\
33 R-1,102-104 \text { to } \\
34 R-1,110-114 \\
34 R-2,110-114 \text { to } \\
34-C C \\
35 R-1,115-119 \\
35 R-2,115-119 \\
35 R-3,115-119 \\
35 R-4,115-119 \\
35 R-5,115-119 \text { to } \\
36 R-3,100-184 \text { to } \\
38 R-2,42-47 \text { to } \\
44 R-5,110-114 \\
44 R-6,109-113 \\
44 R-C C \\
45 R-1,100-103 \\
45 R-2,100-103 \\
45 R-3,100-103 \\
45 R-4,99-102 \text { to } \\
49 R-2,118-122 \text { to } \\
53-C C\end{array}$ & $\begin{array}{l}151.89 \\
180.49 \\
186.49 \\
189.40 \\
189.82 \\
199.00 \\
199.99 \\
201.50 \\
214.17 \\
215.67 \\
218.30 \\
219.12 \\
237.60 \\
306.12 \\
315.90 \\
317.40 \\
324.40 \\
325.55 \\
327.05 \\
328.55 \\
330.05 \\
331.55 \\
338.10 \\
355.32 \\
417.90 \\
419.39 \\
420.50 \\
421.50 \\
423.00 \\
424.50 \\
425.99 \\
461.68 \\
507.40\end{array}$ & $\begin{array}{l}4 \\
8 \\
4 \\
5\end{array}$ & $\begin{array}{l}M \\
G \\
\text { B } \\
G \\
B \\
B \\
G \\
B \\
G \\
G \\
G \\
B \\
G \\
B \\
G \\
B \\
G \\
B \\
G \\
G \\
M \\
B \\
G \\
G \\
G \\
B \\
G \\
B \\
B \\
G \\
G \\
G \\
B\end{array}$ & $\mathrm{R}$ & $\begin{array}{l}\text { cf } \\
\text { R }\end{array}$ & $\begin{array}{l}R \\
R \\
R \\
R \\
R \\
R \\
R \\
F \\
R \\
\\
\\
R \\
R \\
R\end{array}$ & $\begin{array}{l}\mathrm{R} \\
\mathrm{R} \\
\mathrm{R}\end{array}$ & $*$ & $\begin{array}{l}\text { Cold } \\
\text { Temperate }\end{array}$ & 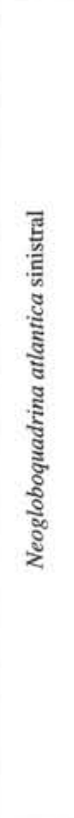 & 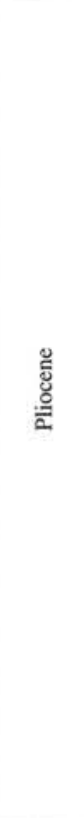 \\
\hline
\end{tabular}

Note: For abbreviations see Table 1.

Planktonic foraminifers are abundant and well preserved in the upper sequence of the Quaternary sediments and occur sporadically in the downhole sequence. Monospecific Neogloboquadrina pachyderma sin. assemblages indicate Quaternary age for Cores 151$912 \mathrm{~A}-1 \mathrm{H}$ through $3 \mathrm{H}$, and $912 \mathrm{~B}-1 \mathrm{H}$ through $4 \mathrm{H}$. Core-catcher samples from Cores 151-912A-4H through $15 \mathrm{X}$ are barren with the exception of a single specimen of N. pachyderma sin. in Sample 151912A-7H-CC. Cores 151-912A-12X and $14 \mathrm{X}$ have no recovery. Six additional samples from Core 151-912A-15X were processed to define the boundary between the Quaternary and the Pliocene. Samples from Sections 151-912A-15X-1, 15X-2, and 15X-4 are barren. Samples from Sections $15 \mathrm{X}-3$ and $15 \mathrm{X}-5$ contain $N$. pachyderma $\sin$., indicating a Quaternary age. Sample 151-912A-15X-5, 33-37 cm, has the dextral coiling juvenile Neogloboquadrina, similar to the se- quence observed at Site 910, where they were observed in the uppermost Pliocene. Sample 151-912A-15X-CC is barren. In the lowermost part of the sequence at Site 912, planktonic foraminifers from Core 151-912C-12R indicate the presence of the Pliocene Neogloboquadrina atlantica $\sin$. Zone.

Ice-rafted Inoceramus-prisms (Cretaceous) are found in Quaternary sediments of Hole 912A and in Samples 151-912C-4R-CC through 11R-CC in Pliocene sediments.

\section{FRAM STRAIT}

The opening of the Fram Strait induced deep-water exchange between the Arctic and the Atlantic Oceans and forced long-term paleo- 
Table 3. Distribution of planktonic foraminifers in Hole 910D.

\begin{tabular}{|c|c|c|c|c|c|c|c|c|c|c|c|c|c|c|c|c|c|}
\hline $\begin{array}{l}\text { Core, section, } \\
\text { interval }(\mathrm{cm})\end{array}$ & $\begin{array}{l}\text { Depth } \\
\text { (mbsf) }\end{array}$ & 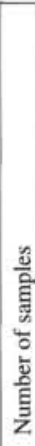 & 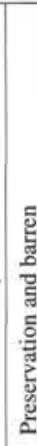 & 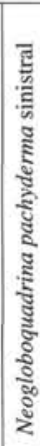 & 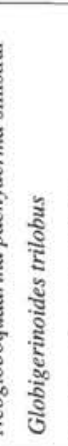 & 离 & 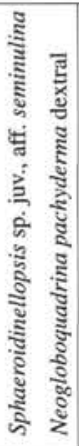 & 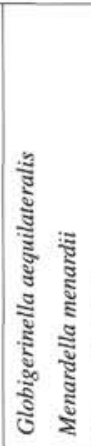 & 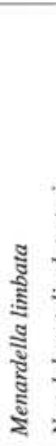 & 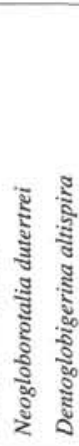 & 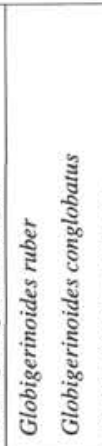 & בै & 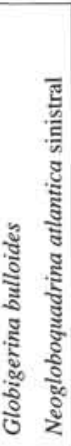 & 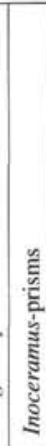 & 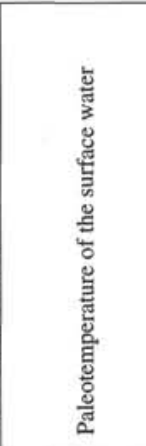 & Zone & Epoch \\
\hline $\begin{array}{l}\text { 151-910D- } \\
1 \mathrm{H}-\mathrm{CC} \text { to } \\
6 \mathrm{X}-1,74-76 \\
6 \mathrm{X}-\mathrm{CC} \text { to } \\
8 \mathrm{X}-1,74-76 \text { to } \\
9 \mathrm{X}-2,75-76 \text { to } \\
10 \mathrm{X}-2,75-77\end{array}$ & $\begin{array}{r}5.80 \\
37.04 \\
45.30 \\
55.64 \\
66.74 \\
76.35\end{array}$ & $\begin{array}{l}6 \\
2 \\
3 \\
3\end{array}$ & $\begin{array}{l}\mathrm{G} \\
\mathrm{M} \\
\mathrm{B} \\
\mathrm{M} \\
\mathrm{B} \\
\mathrm{P}\end{array}$ & $\begin{array}{l}\mathrm{A} \\
\mathrm{R} \\
\mathrm{R}\end{array}$ & & & & & & & & & & * & $\begin{array}{l}\text { Cold } \\
\text { Cold } \\
\text { Cotd } \\
\text { Cold } \\
\text { Cold } \\
\end{array}$ & 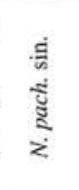 & 总 \\
\hline \begin{tabular}{|l}
$10 X-3,74-76$ \\
$10 X-C C$ \\
$11 X-1,74-76$ to \\
$13 X-2,74-76$ \\
$13 X-3,74-76$ to \\
$14 X-2,74-76$ \\
$14 X-3,74-76$ to \\
$15 X-3,74-76$ \\
$15 X-4,74-76$ to \\
$16 X-2,74-76$ \\
$16 X-3,74-76$ \\
\end{tabular} & \begin{tabular}{r|}
77.84 \\
83.70 \\
84.44 \\
105.24 \\
106.74 \\
114.89 \\
116.34 \\
126.24 \\
127.74 \\
134.14 \\
135.64 \\
\end{tabular} & 12 & $\begin{array}{l}\text { P } \\
\text { G } \\
\text { B } \\
\text { P } \\
\text { B } \\
\text { P } \\
\text { B } \\
\text { G } \\
\text { B } \\
\text { G } \\
\text { G }\end{array}$ & & $\mathrm{R}$ & R $\mathrm{F}$ & ${ }^{R}{ }_{R}$ & $\begin{array}{l}\mathrm{R} \\
\mathrm{R}\end{array}$ & R & $\begin{array}{ll}\mathrm{R} & \mathrm{R} \\
\mathrm{R} & \mathrm{R}\end{array}$ & R R & ${ }^{R}$ & R & * & $\begin{array}{l}\begin{array}{l}\text { Temperate } \\
\text { Temperate }\end{array} \\
\text { Extd } \\
\text { Warm-temp. } \\
\text { Cord } \\
\text { Warm-temp. } \\
\text { Subtropical } \\
\begin{array}{l}\text { Subtropical } \\
\text { Temperate }\end{array}\end{array}$ & $\begin{array}{l}\mathrm{N} 21 \\
\mathrm{~N} 21\end{array}$ & 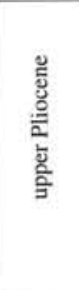 \\
\hline $\begin{array}{l}16 X-5,74-76 \text { to } \\
17 X-2,74-76 \\
17 X-3,74-76 \text { to } \\
17 X-6,74-76 \\
18 X-1,74-76\end{array}$ & $\begin{array}{l}138.64 \\
142.24 \\
143.74 \\
148.24 \\
151.84\end{array}$ & $\begin{array}{l}2 \\
3\end{array}$ & $\begin{array}{l}\mathrm{B} \\
\mathrm{M} \\
\mathrm{B} \\
\mathrm{P} \\
\mathrm{B}\end{array}$ & $\begin{array}{l}\mathrm{R} \\
\mathrm{R}\end{array}$ & & & & & & & & & & * & $\begin{array}{l}\text { Cold } \\
\text { Cold } \\
\text { Cold }\end{array}$ & & हूँ \\
\hline $\begin{array}{l}18 X-2,74-76 \\
18 X-3,74-76 \\
18 X-4,74-76\end{array}$ & $\begin{array}{l}153.34 \\
154.84 \\
156.34\end{array}$ & & $\begin{array}{l}\text { G } \\
\text { G } \\
\text { B }\end{array}$ & R & & & & & & & & & $\begin{array}{l}R \\
R\end{array}$ & & $\begin{array}{l}\text { Cold } \\
\text { Cold }\end{array}$ & 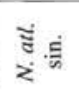 & \\
\hline
\end{tabular}

Note: For abbreviations see Table 1.

climatic changes. Therefore, knowledge of the evolution of the Fram Strait is one of the keys to understanding global oceanic circulation.

\section{Site 909}

Site 909 is located in the Fram Strait, north of Hovgård Ridge, on a small abyssal terrace in $2519 \mathrm{~m}$ water depth at approximately $78^{\circ} 35^{\prime} \mathrm{N}, 3^{\circ} 4^{\prime} \mathrm{E}$. Three holes were drilled. The investigation of planktonic foraminifers is based on Hole 909A (Table 8), which penetrated $92.5 \mathrm{~m}$ sediment, and on Hole 909C (Table 9) cored from $85 \mathrm{mbsf}$ into Miocene sediments down to $1061.8 \mathrm{mbsf}$. Dissolution may strongly affect the sediments in the Miocene sequence at this site, and the original planktonic foraminifer assemblages are not preserved. Therefore other fossil groups need to be examined to produce a useful biostratigraphy. We analyzed 64 samples from Hole 909A, and 335 samples from Hole 909C.

The Quaternary Neogloboquadrina pachyderma sin. Zone is documented in Hole 909A from the top of the sequence down to Sample $151-909 \mathrm{~A}-8 \mathrm{H}-\mathrm{CC}$. The assemblages are low in diversity and dominated by the polar $N$. pachyderma sin. The planktonic foraminifer abundance varies considerably (as documented in Myhre, Thiede, Firth, et al., 1995), typifying the changes between glacial and more interglacial conditions. An interval barren in planktonic foraminifers separates the Quaternary N. pachyderma $\sin$. Zone from the Pliocene Neogloboquadrina atlantica $\sin$. Zone. This barren interval is documented in Samples 151-909A-9H-CC through 11H-CC and in Samples 151-909C-1R-CC through 8R-CC. The Pliocene $N$. atlantica sin.
Zone is present from Samples 151-909C-9R-1, 86-88 cm, to 32R-3, $28-32 \mathrm{~cm}$. The first observation of ice-rafted Inoceramus-prisms was in Sample 151-909C-10R-CC at $181.60 \mathrm{mbsf}$ in this zone. Planktonic foraminifer species of the late Pliocene include $N$. atlantica sin. and Neogloboquadrina asanoi. The latter species is more common in the Pacific region than in the Atlantic. A single observation of Globoconella inflata in Sample 151-909C-31R-3, 23-28 cm, confirms the upper Pliocene down to $377.33 \mathrm{mbsf}$. The $N$. atlantica Superzone, spanning Pliocene to latest Miocene (Spiegler and Jansen, 1989) is documented down to Sample 151-909C-32R-3, 28-32 cm at 386.88 mbsf. All samples between Section 151-909C-32R-5, 28-32 cm, and $44 \mathrm{R}-1,32-35 \mathrm{~cm}$, are barren of planktonic foraminifers. Downhole, agglutinated foraminifers dominate the assemblages. Nevertheless, planktonic foraminifers occurred in $10 \%$ of the samples. In Sample 151-909C-76R-1, 96-98 cm, at 808.56 mbsf the FO (first observation) of Globigerina bulloides indicates the upper Miocene. The FO of Orbulina universa in Sample 151-909C-89R-1, 97-100 cm, at 934.07 mbsf is important, because this FA (first appearance) defines a worldwide datum that coincides approximately with the beginning of planktonic foraminifer Zone N9 in the middle Miocene at 15.1 Ma. The occurrence of Globorotalia scitula (range N9 to Recent) in Sample 151-909C-103R-2, 3-7 cm, at 1059.53 mbsf indicates also an age younger than 15.1 Ma. Therefore, the oldest fossiliferous sediments penetrated at Site 909 are of early middle Miocene age. Section 151909C-103R-3 and the core-catcher sample of Core 103R are barren. Reworking is evident by abundances of megaspores in Samples 151909C-88R-CC and 89R-2, 97-99 cm. 
Table 4. Distribution of planktonic foraminifers in Hole 910A.

\begin{tabular}{|c|c|c|c|c|c|c|c|c|c|c|}
\hline $\begin{array}{l}\text { Core, section, } \\
\text { interval }(\mathrm{cm})\end{array}$ & $\begin{array}{l}\text { Depth } \\
\text { (mbsf) }\end{array}$ & 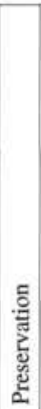 & 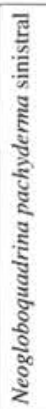 & 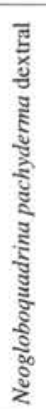 & 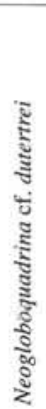 & 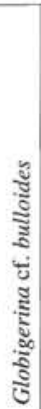 & 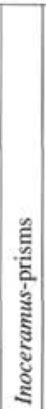 & 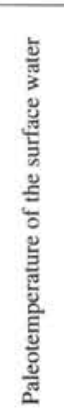 & Zone & Epoch \\
\hline $\begin{array}{l}151-910 \mathrm{~A}- \\
1 \mathrm{H}-1,24-26 \\
1 \mathrm{H}-2,24-26 \\
1 \mathrm{H}-3,4-6 \\
1 \mathrm{H}-4,8-10 \\
1 \mathrm{H}-\mathrm{CC} \\
2 \mathrm{H}-1,20-22 \\
2 \mathrm{H}-2,20-22 \\
2 \mathrm{H}-3,20-22 \\
2 \mathrm{H}-4,20-22 \\
2 \mathrm{H}-5,20-22 \\
2 \mathrm{H}-6,20-22 \\
2 \mathrm{H}-\mathrm{CC}, 20-22 \\
2 \mathrm{H}-\mathrm{CC} \\
3 \mathrm{H}-1,15-19 \\
3 \mathrm{H}-2,15-19 \\
3 \mathrm{H}-3,15-19 \\
3 \mathrm{H}-\mathrm{CC}, 14-18 \\
3 \mathrm{H}-\mathrm{CC} \\
4 \mathrm{H}-1,13-17 \\
4 \mathrm{H}-2,24-28 \\
4 \mathrm{H}-3,13-17 \\
4 \mathrm{H}-4,4-8 \\
4 \mathrm{H}-\mathrm{CC} \\
5 \mathrm{X}-\mathrm{CC}, 9-13 \\
5 \mathrm{X}-\mathrm{CC}\end{array}$ & $\begin{array}{r}0.24 \\
1.74 \\
3.04 \\
4.58 \\
5.50 \\
5.70 \\
7.20 \\
8.70 \\
10.20 \\
11.70 \\
13.20 \\
14.70 \\
15.00 \\
15.15 \\
16.65 \\
18.15 \\
19.50 \\
19.50 \\
19.63 \\
21.24 \\
22.63 \\
24.04 \\
24.50 \\
34.00 \\
34.00\end{array}$ & $\begin{array}{l}\mathrm{G} \\
\mathrm{G} \\
\mathrm{G} \\
\mathrm{G} \\
\mathrm{G} \\
\mathrm{G} \\
\mathrm{G} \\
\mathrm{G} \\
\mathrm{G} \\
\mathrm{G} \\
\mathrm{G} \\
\mathrm{G} \\
\mathrm{G} \\
\mathrm{G} \\
\mathrm{G} \\
\mathrm{G} \\
\mathrm{G} \\
\mathrm{G} \\
\mathrm{G} \\
\mathrm{G} \\
\mathrm{G} \\
\mathrm{G} \\
\mathrm{G} \\
\mathrm{G} \\
\mathrm{G}\end{array}$ & $\begin{array}{l}\text { A } \\
C \\
C \\
C \\
C \\
A \\
C \\
C \\
C \\
C \\
C \\
C \\
C \\
A \\
R \\
C \\
C \\
C \\
C \\
C \\
C \\
C \\
C \\
C \\
C \\
C\end{array}$ & $\begin{array}{l}\mathrm{R} \\
\mathrm{R}\end{array}$ & $\begin{array}{l}\mathrm{R} \\
\mathrm{R}\end{array}$ & $\begin{array}{l}R \\
R \\
R \\
R \\
\\
R \\
R \\
R\end{array}$ & 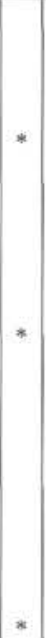 & $\begin{array}{l}\text { Cold } \\
\text { Cold } \\
\text { Cold } \\
\text { Cold } \\
\text { Cold } \\
\text { Cold } \\
\text { Cold } \\
\text { Cold } \\
\text { Cold } \\
\text { Cold } \\
\text { Cold } \\
\text { Cold } \\
\text { Cold } \\
\text { Cold } \\
\text { Cold } \\
\text { Cold } \\
\text { Cold } \\
\text { Cold } \\
\text { Cold } \\
\text { Cold } \\
\text { Cold } \\
\text { Cold } \\
\text { Cold } \\
\text { Cold } \\
\text { Cold }\end{array}$ & 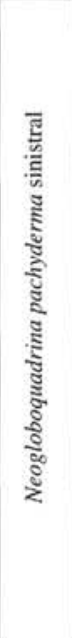 & 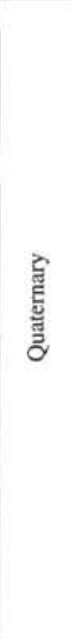 \\
\hline
\end{tabular}

Note: For abbreviations see Table 1.

Table 5. Distribution of planktonic foraminifers in Hole 912A.

\begin{tabular}{|c|c|c|c|c|c|c|c|c|}
\hline $\begin{array}{l}\text { Core, section, } \\
\text { interval }(\mathrm{cm})\end{array}$ & $\begin{array}{l}\text { Depth } \\
\text { (mbsf) }\end{array}$ & 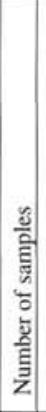 & 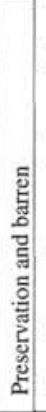 & 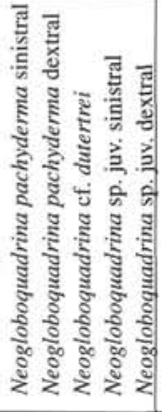 & है & 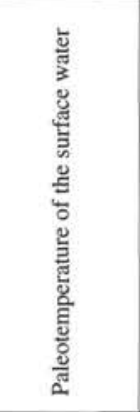 & Zone & Epoch \\
\hline $\begin{array}{l}151-912 \mathrm{~A}- \\
1 \mathrm{H}-\mathrm{CC} \text { to } \\
4 \mathrm{H}-\mathrm{CC} \text { to } \\
7 \mathrm{H}-\mathrm{CC} \\
8 \mathrm{H}-\mathrm{CC} \text { to } \\
12 \mathrm{H}-\mathrm{CC} \\
13 \mathrm{H}-\mathrm{CC} \\
14 \mathrm{H}-\mathrm{CC} \\
15 \mathrm{H}-1,33-37 \text { to } \\
15 \mathrm{X}-3,33-37 \\
15 \mathrm{X}-4,33-37 \\
15 \mathrm{X}-5,33-37\end{array}$ & $\begin{array}{r}0.04 \\
32.00 \\
61.00 \\
70.50 \\
106.90 \\
116.50 \\
126.10 \\
126.43 \\
128.98 \\
130.48 \\
131.93\end{array}$ & $\begin{array}{l}4 \\
3 \\
4 \\
2\end{array}$ & 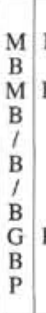 & $\begin{array}{l}F \quad R \quad R \\
R\end{array}$ & * & $\begin{array}{l}\text { Cold } \\
\text { Cold } \\
\text { Cotd } \\
\text { No recontery } \\
\text { Nortsconery } \\
\text { Cold } \\
\text { Cold }\end{array}$ & 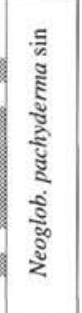 & 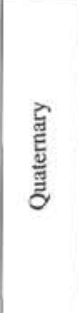 \\
\hline $15 X-6,33-37$ & 133.43 & & $\mathrm{P}$ & $\mathrm{R}$ & & Cold & \#1 & \#2 \\
\hline $15 \mathrm{X}-\mathrm{CC}$ & 135.80 & & B & & & & & iren \\
\hline
\end{tabular}

Notes: \#1 = Neogloboquadrina sp. juv. dextral, \#2 = Pliocene. For other abbreviations see Table 1.
Table 6. Distribution of planktonic foraminifers in Hole 912B.

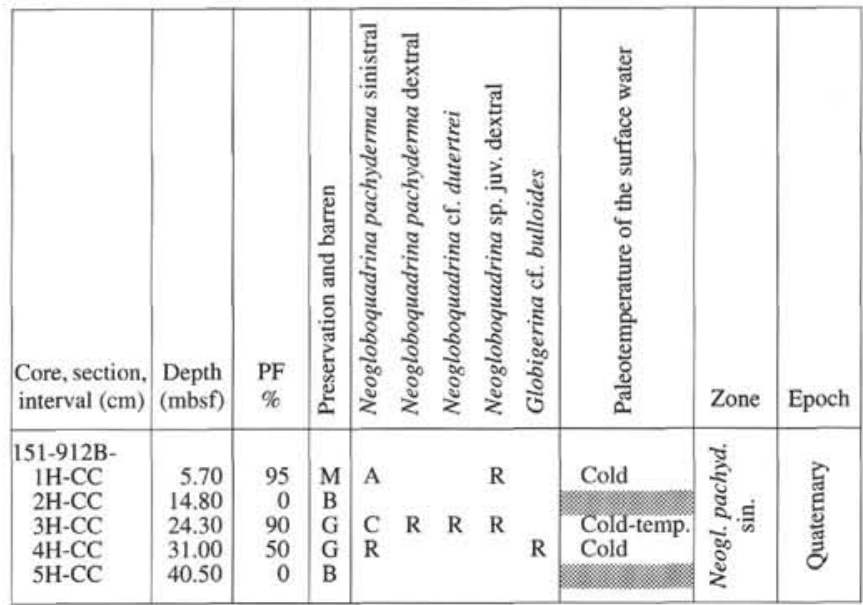

Note: For abbreviations see Table 1.

Table 7. Distribution of planktonic foraminifers in Hole 912C.

\begin{tabular}{|c|c|c|c|c|c|c|c|}
\hline $\begin{array}{l}\text { Core, section, } \\
\text { interval }(\mathrm{cm})\end{array}$ & $\begin{array}{l}\text { Depth } \\
\text { (mbsf) }\end{array}$ & 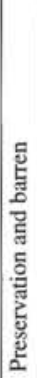 & 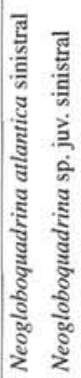 & 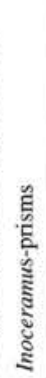 & 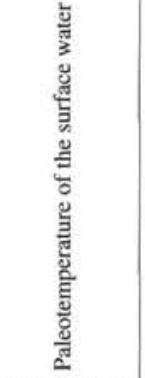 & Zone & Epoch \\
\hline $\begin{array}{c}151-912 \mathrm{C}- \\
1 \mathrm{R}-\mathrm{CC} \\
2 \mathrm{R}-\mathrm{CC} \\
3 \mathrm{R}-\mathrm{CC} \\
4 \mathrm{R}-\mathrm{CC} \\
5 \mathrm{R}-\mathrm{CC} \\
6 \mathrm{R}-\mathrm{CC} \\
7 \mathrm{R}-\mathrm{CC} \\
8 \mathrm{R}-\mathrm{CC} \\
9 \mathrm{R}-\mathrm{CC} \\
10 \mathrm{R}-\mathrm{CC} \\
11 \mathrm{R}-\mathrm{CC}\end{array}$ & $\begin{array}{l}103.10 \\
112.70 \\
122.40 \\
132.00 \\
141.70 \\
151.30 \\
160.90 \\
170.60 \\
180.20 \\
189.90 \\
199.50\end{array}$ & $\begin{array}{l}\mathrm{B} \\
\mathrm{B} \\
\mathrm{B} \\
\mathrm{B} \\
\mathrm{B} \\
\mathrm{B} \\
\mathrm{B} \\
\mathrm{B} \\
\mathrm{B} \\
\text { I } \\
\mathrm{B}\end{array}$ & & $\begin{array}{l}* \\
* \\
* \\
* \\
*\end{array}$ & 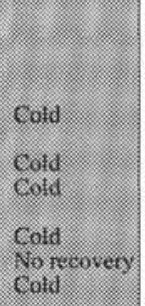 & \multicolumn{2}{|c|}{ 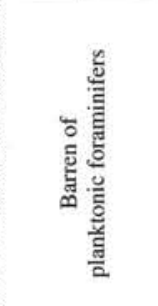 } \\
\hline $\begin{array}{l}12 \mathrm{R}-1,89-94 \\
12 \mathrm{R}-2,39-43 \\
12 \mathrm{R}-3,16-19 \\
12 \mathrm{R}-\mathrm{CC}\end{array}$ & $\begin{array}{l}200.39 \\
202.39 \\
202.66 \\
209.10\end{array}$ & $\begin{array}{l}\text { G } \\
\text { G } \\
\text { G } \\
\text { G }\end{array}$ & \multicolumn{2}{|l|}{ R } & & 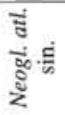 & 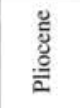 \\
\hline
\end{tabular}

Note: For abbreviations see Table 1.

\section{Site 908}

The southern opening of the Fram Strait is almost completely blocked by the Hovgård Ridge (Myhre, Thiede, Firth, et al., 1995). Small sediment basins on the Hovgård Ridge contain sediments documenting the geological history of the structural high after subsidence and the opening of Fram Strait. Site 908 is located on top of the Hovgård Ridge in about $1273 \mathrm{~m}$ water depth at approximately $78^{\circ} 23^{\prime} \mathrm{N}, 1^{\circ} 22^{\prime} \mathrm{E}$. Hole $908 \mathrm{~A}$ (Table 10 ) penetrated $344.6 \mathrm{~m}$ of sediment, reaching upper Oligocene sediments. Hole 908B drilled $83.4 \mathrm{~m}$ and terminated in Pliocene sediments.

The biostratigraphic results are based on Hole 908A. Unfortunately, planktonic foraminifers occurred only in the upper $15 \mathrm{~m}$ of the sequence, down to Sample 151-908A-2H-CC. In this interval nearly monospecific associations of the polar-adopted $N$. pachyderma sin. 
Table 8. Distribution of planktonic foraminifers in Hole 909A.

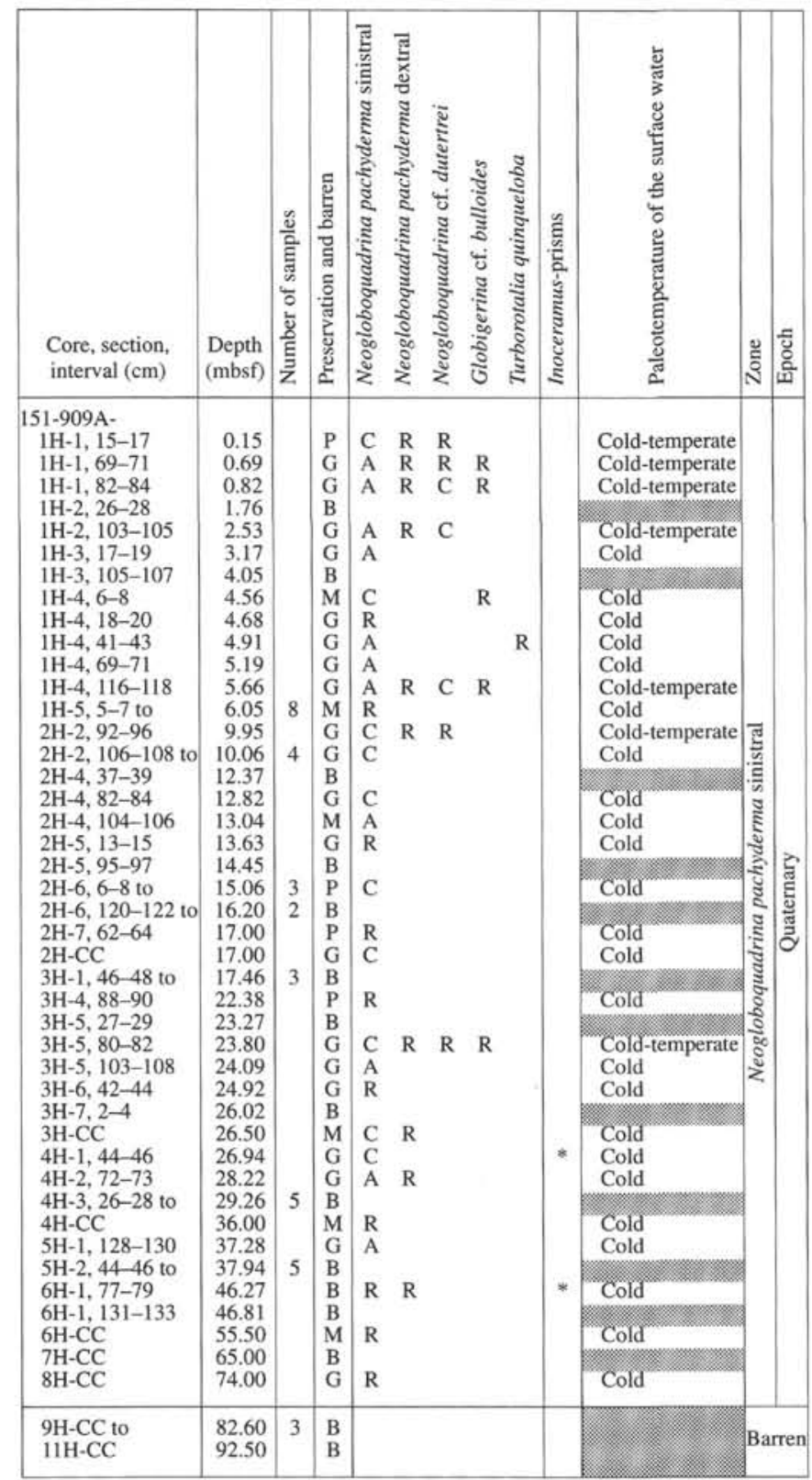

occurred, suggesting an age assignment to the Quaternary. The assemblages show highly variable abundances, fluctuating several times from abundant to intervals rare or even barren in planktonic foraminifers. Further, one sample per section down to Sample 151$908-28 X-6,95-100 \mathrm{~cm}$ (263.05 mbsf) was analyzed. Because of no success, analysis was halted.

\section{EAST GREENLAND MARGIN} Site 913

Site 913 is located in the Greenland Basin. Two holes were drilled at $3.318 \mathrm{~m}$ water depth at $75^{\circ} 29.3^{\prime} \mathrm{N}, 6^{\circ} 56.8^{\prime} \mathrm{W}$. This site was selected to evaluate the onset and history of the East Greenland Current, to monitor the development of deep-water formation in the Greenland
Sea, and to document the history of IRD input, as well as to determine the age and character of sediments overlying basement (Myhre, Thiede, Firth, et al., 1995).

Hole $913 \mathrm{~A}$ (Table 11) penetrated to $84.40 \mathrm{~m}$. The planktonic foraminifer assemblages are low in diversity and dominated by the polar $N$. pachyderma sin. The abundance varies considerably, as documented above, in the other northern sites of this leg. Ice-rafted Inoceramus-prisms are documented down to $65.10 \mathrm{mbsf}$. Sample 151913A-12X-CC was barren, and the last core of Hole 913A had no recovery. We analyzed 38 samples from Hole $913 \mathrm{~A}$.

Poor recovery severely hampered the analysis of the Quaternary and late Neogene sediments of Hole 913B to $375.20 \mathrm{mbsf}$. After washing down to $423.50 \mathrm{~m}$, all core-catcher samples of this hole were analyzed. They contained no planktonic foraminifers. Osterman and Spiegler (this volume) analyzed the agglutinated benthic assemblages of Site 913. Out of the 300 samples studied, planktonic foraminifers were seen in only three samples. Sample 151-913B-24R-4, 10$14 \mathrm{~cm}$, at $466.60 \mathrm{mbsf}$ contained a single broken specimen of a small Acarinina sp., aff. A. rotundimarginata Subbotina (1953), a species that is typical for the middle Eocene. Silicified Subbotina triangularis (White) were found in the Samples 151-913B-44R-3, 58-60 $\mathrm{cm}$, and 45R-1, 11-14 cm, at $658.09 \mathrm{mbsf}$ and $664.51 \mathrm{mbsf}$, respectively, reaching stratigraphically from Zone P2 (Paleocene) to Zone P8a (early Eocene). Nevertheless, lacking Paleocene species in this sequence, an age assignment to early Eocene is supposed.

\section{SUMMARY}

Age determinations of the sediments recovered during Leg 151 are difficult due to the scarcity of planktonic foraminifers and poorly diversified assemblages. Temperature is the most important factor controlling habitat of planktonic foraminifers in high latitudes.

The summary of the planktonic foraminifer zones and some ages, derived from different FOs or LOs of planktonic foraminifers at Sites 908 through 913, is given in Figure 2.

In the Quaternary sediments, the polar Neogloboquadrina pachyderma sin. is the dominant species and shows highly variable abundances. The alternations seem to be related to the changes between glacial and cold (interglacial) conditions. The whole Quaternary may be characterized as the Neogloboquadrina pachyderma sin. Zone. The LO of Neogloboquadrina atlantica marks the Quaternary/ Pliocene boundary. The $N$. atlantica Superzone spans the whole Pliocene and reaches into the late Miocene. A further subdivision of this interval by coiling changes of $N$. atlantica is impossible. Warm to subtropical intervals in the upper Neogloboquadrina atlantica sin. Zone can be correlated with the planktonic foraminifer Zone N21. Therefore, the late Pliocene may be characterized as cold or coldtemperate with episodic ingressions of warm to subpolar surface water. The co-occurrence of Neogloboquadrina asanoi marks the influence of Pacific surface water in the late Pliocene.

Rare and spot occurrences of planktonic foraminifers in the Miocene and Paleogene sediments prevent a zonation. The oldest sediments recovered at the East Greenland Margin are of early Eocene age.

\section{ACKNOWLEDGMENTS}

I feel privileged to be reviewed by such outstanding professionals as P.P.E. Weaver, W.A. Berggren, and W.F. Ruddiman. I greatly appreciate the topotype material of $N$. asanoi, given by T. Sato. I am indebted to F. Rack, who made available samples of Hole 910D. To the technicians A. Maas, T.M. Kusche, A. von Doetinchem, and J. Heinze (all Kiel) I owe special gratitude. Financial support by the Deutsche Forschungsgemeinschaft (Grant Th 200/17) is acknowledged. 
Table 9. Distribution of planktonic foraminifers in Hole 909C.

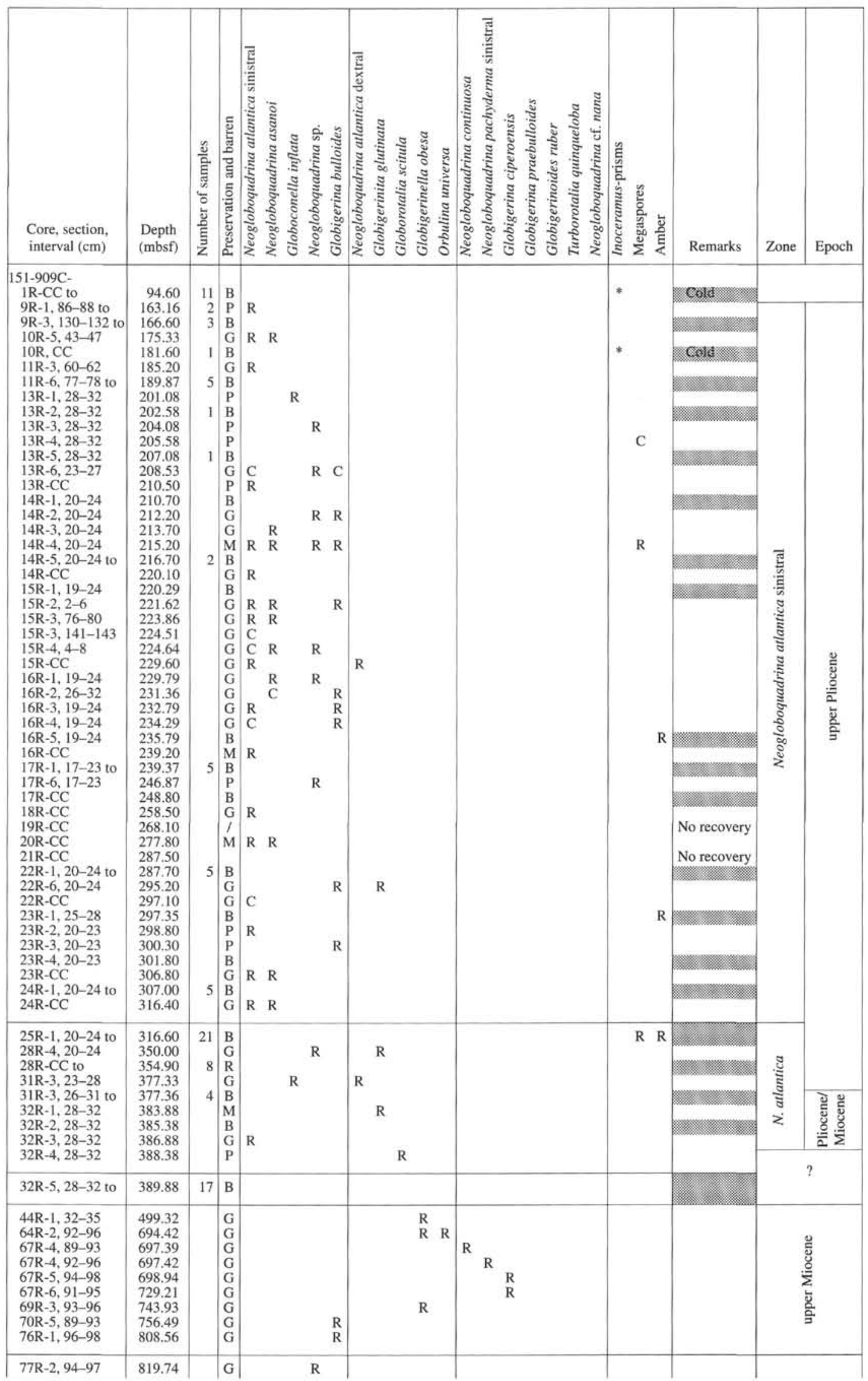


Table 9 (continued).

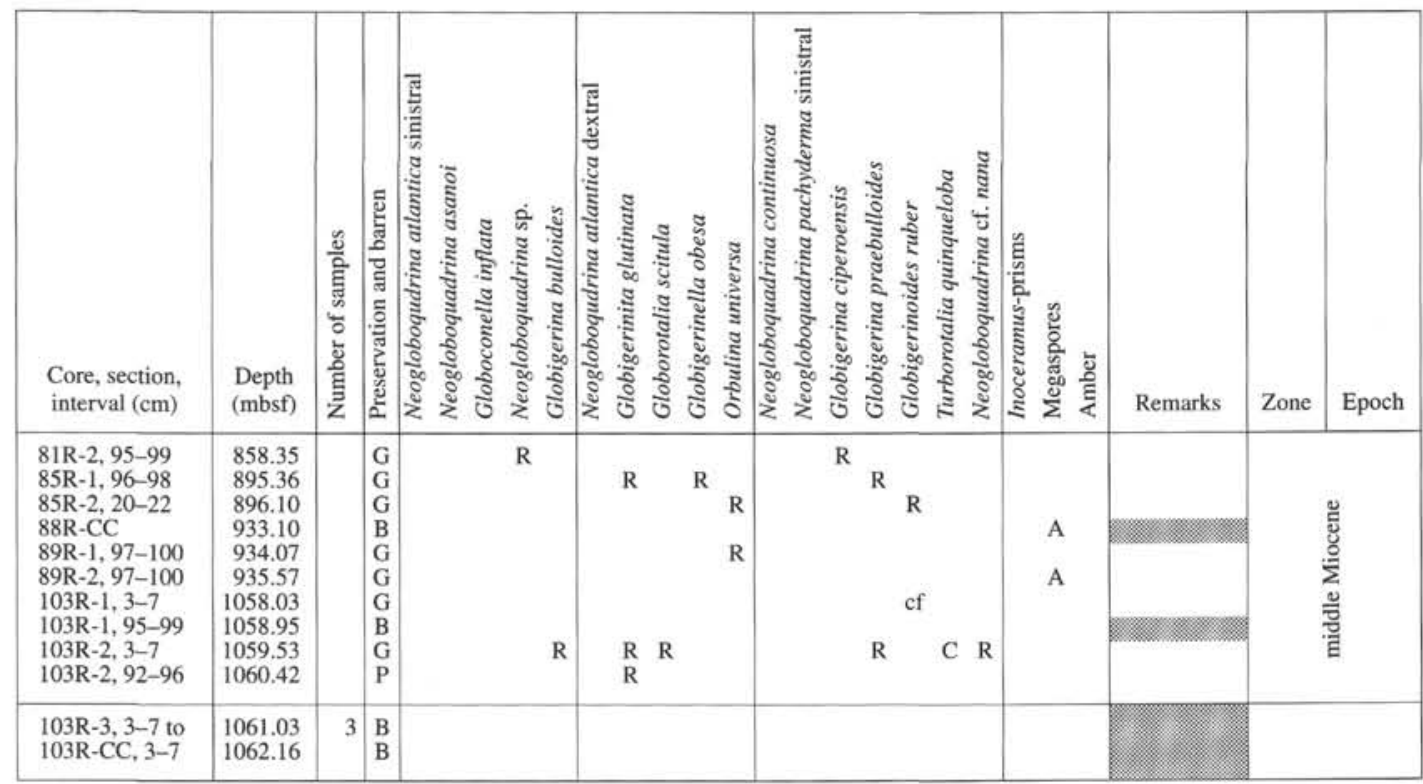

Note: For abbreviations see Table 1.

Table 10. Distribution of planktonic foraminifers in Hole 908A.

\begin{tabular}{|c|c|c|c|c|c|c|c|c|}
\hline $\begin{array}{l}\text { Core, section, } \\
\text { interval }(\mathrm{cm})\end{array}$ & $\begin{array}{l}\text { Depth } \\
\text { (mbsf) }\end{array}$ & 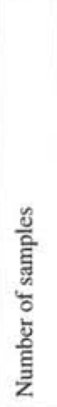 & 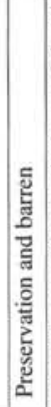 & 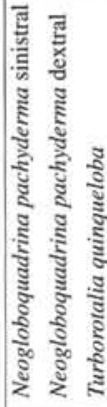 & 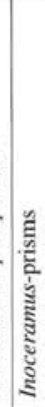 & 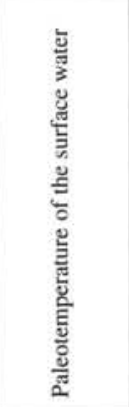 & Zone & Epoch \\
\hline $\begin{array}{l}151-908 \mathrm{~A}- \\
1 \mathrm{H}-1,5-10 \\
1 \mathrm{H}-1,21-23 \\
1 \mathrm{H}-1,43-46 \\
1 \mathrm{H}-1,47-48 \\
1 \mathrm{H}-1,70-75 \\
1 \mathrm{H}-1,134-139 \\
1 \mathrm{H}-4,64-66 \\
1 \mathrm{H}-\mathrm{CC}, 17-19 \\
1 \mathrm{H}-\mathrm{CC} \\
2 \mathrm{H}-1,69-72 \\
2 \mathrm{H}-2,71-75 \\
2 \mathrm{H}-3,38-42 \\
2 \mathrm{H}-3,135-139 \\
2 \mathrm{H}-6,54-57 \\
2 \mathrm{H}-6,57-69 \\
2 \mathrm{H}-7,65-69 \\
2 \mathrm{H}-\mathrm{CC}\end{array}$ & \begin{tabular}{|c|}
0.05 \\
0.21 \\
0.43 \\
0.47 \\
0.70 \\
1.34 \\
5.14 \\
5.34 \\
5.40 \\
6.09 \\
6.11 \\
8.78 \\
9.75 \\
13.44 \\
13.57 \\
$\mathrm{ca} .14 .50$ \\
14.90
\end{tabular} & $\begin{array}{l}1 \\
5 \\
1 \\
1\end{array}$ & $\begin{array}{l}\mathrm{M} \\
\mathrm{B} \\
\mathrm{M} \\
\mathrm{M} \\
\mathrm{B} \\
\mathrm{M} \\
\mathrm{B} \\
\mathrm{M} \\
\mathrm{G} \\
\mathrm{M} \\
\mathrm{P} \\
\mathrm{B} \\
\mathrm{G} \\
\mathrm{B} \\
\mathrm{G} \\
\mathrm{B} \\
\mathrm{M}\end{array}$ & $\begin{array}{lll}R & R \\
A & R & \\
A & & \\
R & R \\
R & & \\
C & R & R \\
R & & \\
R & & \\
A & & \\
R & & \\
R & & \end{array}$ & * & 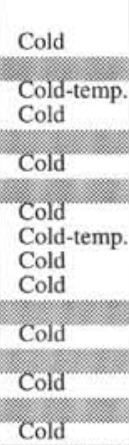 & 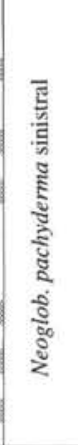 & 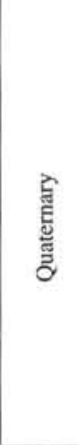 \\
\hline $\begin{array}{l}3 \mathrm{H}-1,37-42 \text { to } \\
28 \mathrm{X}-6,95-100\end{array}$ & $\begin{array}{r}15.27 \\
263.05\end{array}$ & 150 & $\begin{array}{l}\text { B } \\
\text { B }\end{array}$ & & & & & $\begin{array}{l}\text { Irren } \\
\mathrm{PF}\end{array}$ \\
\hline
\end{tabular}

Note: For abbreviations see Table 1.

\section{REFERENCES}

Berggren, W.A., 1972. Cenozoic biostratigraphy and paleobiogeography of the North Atlantic. In Laughton, A.S., Berggren, W.A., et al., Init. Repts. DSDP, 12: Washington (U.S. Govt. Printing Office), 965-1002.
Blow, W.H., 1969. Late middle Eocene to Recent planktonic foraminiferal biostratigraphy. In Brönnimann, P., and Renz, H.H. (Eds.), Proc. First Int. Conf. Planktonic Microfossils, Geneva, 1967: Leiden (E.J. Brill), 1:199-422.

, 1979. The Cainozoic Globigerinida: Leiden (E.J. Brill).

Bolli, H.M., and Saunders, J.B., 1985. Oligocene to Holocene low latitude planktonic foraminifera. In Bolli, H.M., Saunders, J.B., and PerchNielsen, K. (Eds.), Plankton Stratigraphy: Cambridge (Cambridge Univ. Press), 155-262.

Kennett, J.P., and Srinivasan, M.S., 1980. Surface ultrastructural variation in Neogloboquadrina pachyderma (Ehrenberg): phenotypic variation and phylogeny in the late Cenozoic. Spec. Publ.-Cushman Found. Foraminiferal Res., 19:134-162.

1983. Neogene Planktonic Foraminifera: A Phylogenetic Atlas: Stroudsburg, PA (Hutchinson Ross).

Myhre, A.M., Thiede, J., Firth, J.V., et al., 1995. Proc. ODP, Init. Repts., 151: College Station, TX (Ocean Drilling Program).

Paul, C.R., 1992. Milankovitch cycles and microfossils: principles and practice of palaeoecological analysis illustrated by Cenomanian chalk-marl rhythms. J. Micropaleontol., 11:95-105.

Poore, R.Z., 1979. Oligocene through Quaternary planktonic foraminiferal biostratigraphy of the North Atlantic: DSDP Leg 49. In Luyendyk, B.P., Cann, J.R., et al., Init. Repts. DSDP, 49: Washington (U.S. Govt. Printing Office), 447-517.

Poore, R.Z., and Berggren, W.A., 1975. Late Cenozoic planktonic foraminifera biostratigraphy and paleoclimatology of Hatton-Rockall Basin: DSDP Site 116. J. Foraminiferal Res., 5:270-293.

Spiegler, D., and Jansen, E., 1989. Planktonic foraminifer biostratigraphy of Norwegian Sea sediments: ODP Leg 104. In Eldholm, O., Thiede, J., Taylor, E., et al., Proc. ODP, Sci. Results, 104: College Station, TX (Ocean Drilling Program), 681-696.

Subbotina, N.N., 1953. Iskopaemye foraminifery SSSR: Globigerinidae, Hantkeninidae, i Globorotaliidae. Tr. Vses. Nauchno-Issled. Geologorazved. Neft. Inst. (VNIGRI), 76.

Weaver, P.P.E., and Clement, B.M., 1986. Synchroneity of Pliocene planktonic foraminiferal datums in the North Atlantic. Marine Micropaleont., 10:295-307.

Date of initial receipt: 14 July 1995

Date of acceptance: 1 December 1995

Ms 151SR-104 
Table 11. Distribution of planktonic foraminifers in Hole 913A.

\begin{tabular}{|c|c|c|c|c|c|c|c|c|c|c|c|c|c|}
\hline $\begin{array}{l}\text { Core, section, } \\
\text { interval }(\mathrm{cm})\end{array}$ & $\begin{array}{l}\text { Depth } \\
\text { (mbsf) }\end{array}$ & 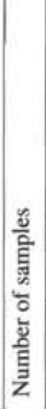 & 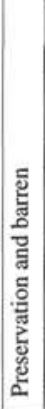 & 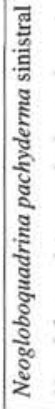 & 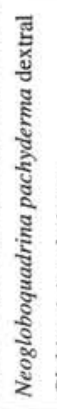 & 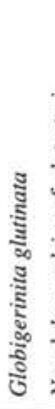 & 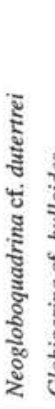 & 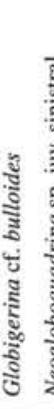 & 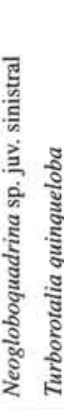 & 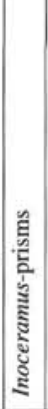 & 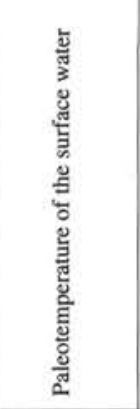 & Zone & Epoch \\
\hline $\begin{array}{l}151-913 \mathrm{~A}- \\
1 \mathrm{H}-1,10-14 \\
1 \mathrm{H}-1,52-55 \\
1 \mathrm{H}-1,86-90 \\
1 \mathrm{H}-2,10-14 \\
1 \mathrm{H}-2,86-90 \\
1 \mathrm{H}-2,129-133 \\
1 \mathrm{H}-3,10-14 \\
1 \mathrm{H}-\mathrm{CC} \\
2 \mathrm{H}-\mathrm{CC} \\
3 \mathrm{H}-1,0-2 \\
3 \mathrm{H}-1,10-14 \\
3 \mathrm{H}-2,10-12 \\
3 \mathrm{H}-3,10-14 \\
3 \mathrm{H}-5,10-14 \text { to } \\
4 \mathrm{H}-2,11-15 \\
4 \mathrm{H}-3,9-13 \text { to } \\
4 \mathrm{H}-\mathrm{CC}, 9-13 \\
4 \mathrm{H}-\mathrm{CC} \\
5 \mathrm{H}-1,10-14 \\
5 \mathrm{H}-2,6-10 \\
5 \mathrm{H}-3,7-11 \\
5 \mathrm{H}-\mathrm{CC} \\
6 \mathrm{H}-\mathrm{CC} \text { to } \\
7 \mathrm{X}-\mathrm{CC} \\
8 \mathrm{X}-\mathrm{CC} \\
9 \mathrm{X}-1,13-15 \text { to } \\
10 \mathrm{X}-1,9-12 \\
10 \mathrm{X}-1,25-29 \\
10 \mathrm{X}-1,87-89 \\
10 \mathrm{X}-\mathrm{CC} \\
11 \mathrm{X}-\mathrm{CC}\end{array}$ & $\begin{array}{r}0.10 \\
0.52 \\
0.86 \\
1.60 \\
2.36 \\
2.79 \\
3.10 \\
4.40 \\
9.30 \\
9.31 \\
9.40 \\
10.90 \\
12.40 \\
15.40 \\
19.21 \\
20.69 \\
23.30 \\
23.60 \\
23.70 \\
25.16 \\
25.76 \\
26.40 \\
36.10 \\
45.80 \\
55.50 \\
55.63 \\
65.19 \\
65.35 \\
65.97 \\
74.70 \\
84.40\end{array}$ & $\begin{array}{l}1 \\
3 \\
3\end{array}$ & $\begin{array}{l}\text { G } \\
\text { G } \\
\text { G } \\
\text { G } \\
\text { G } \\
\text { G } \\
\text { G } \\
\text { G } \\
\text { G } \\
\text { M } \\
\text { G } \\
\text { B } \\
\text { G } \\
\text { B } \\
\text { G } \\
\text { B } \\
\text { G } \\
\text { G } \\
\text { G } \\
\text { G } \\
\text { G } \\
\text { G } \\
\text { B } \\
\text { G } \\
\text { M } \\
\text { B } \\
\text { G } \\
\text { G } \\
\text { G } \\
\text { G } \\
\text { G }\end{array}$ & $\begin{array}{l}\mathrm{A} \\
\mathrm{A} \\
\mathrm{A} \\
\mathrm{A} \\
\mathrm{A} \\
\mathrm{A} \\
\mathrm{A} \\
\mathrm{A} \\
\mathrm{A} \\
\mathrm{R} \\
\\
\mathrm{R} \\
\mathrm{R} \\
\mathrm{C} \\
\mathrm{C} \\
\mathrm{C} \\
\mathrm{C} \\
\mathrm{C} \\
\mathrm{C} \\
\mathrm{R} \\
\mathrm{R} \\
\mathrm{R} \\
\mathrm{C} \\
\mathrm{C} \\
\mathrm{R} \\
\mathrm{C}\end{array}$ & $\begin{array}{l}\mathrm{R} \\
\mathrm{C} \\
\mathrm{R} \\
\mathrm{R} \\
\mathrm{C} \\
\mathrm{A} \\
\mathrm{R}\end{array}$ & $\begin{array}{l}\mathrm{R} \\
\mathrm{R} \\
\mathrm{R}\end{array}$ & $\begin{array}{l}\mathrm{R} \\
\mathrm{C} \\
\mathrm{R}\end{array}$ & $\begin{array}{l}\mathrm{R} \\
\mathrm{R}\end{array}$ & $\begin{array}{ll}\mathrm{C} & \\
& \\
\mathrm{C} & \\
\mathrm{A} & \mathrm{R} \\
\mathrm{A} & \mathrm{R} \\
& \mathrm{R}\end{array}$ & * & $\begin{array}{l}\text { Cold-temp. } \\
\text { Cold-temp. } \\
\text { Cold-temp. } \\
\text { Cold-temp. } \\
\text { Cold-temp. } \\
\text { Cold-temp. } \\
\text { Cold-temp. } \\
\text { Cold } \\
\text { Cold-temp. } \\
\text { Cold } \\
\text { Cold } \\
\text { Cold } \\
\text { cord } \\
\text { Cold } \\
\text { cotd } \\
\text { Cold } \\
\text { Cold } \\
\text { Cold } \\
\text { Cold } \\
\text { Cold } \\
\text { Cold } \\
\text { cord } \\
\text { Cold } \\
\text { Cold } \\
\text { Cstd } \\
\text { Cold } \\
\text { Cold } \\
\text { Cold } \\
\text { Cold } \\
\text { Cold }\end{array}$ & 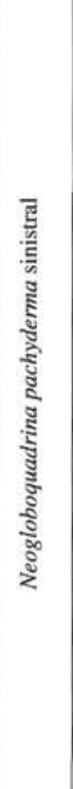 & 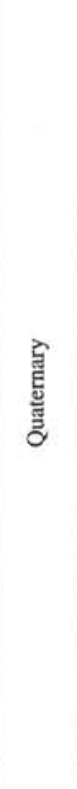 \\
\hline $\begin{array}{l}12 \mathrm{X}-\mathrm{CC} \\
13 \mathrm{X}-\mathrm{CC}\end{array}$ & $\begin{array}{r}94.00 \\
103.60\end{array}$ & & $\begin{array}{l}\mathrm{B} \\
/\end{array}$ & & & & & & & & No recovery & \multicolumn{2}{|c|}{ Barren } \\
\hline
\end{tabular}

Note: For abbreviations see Table 1. 


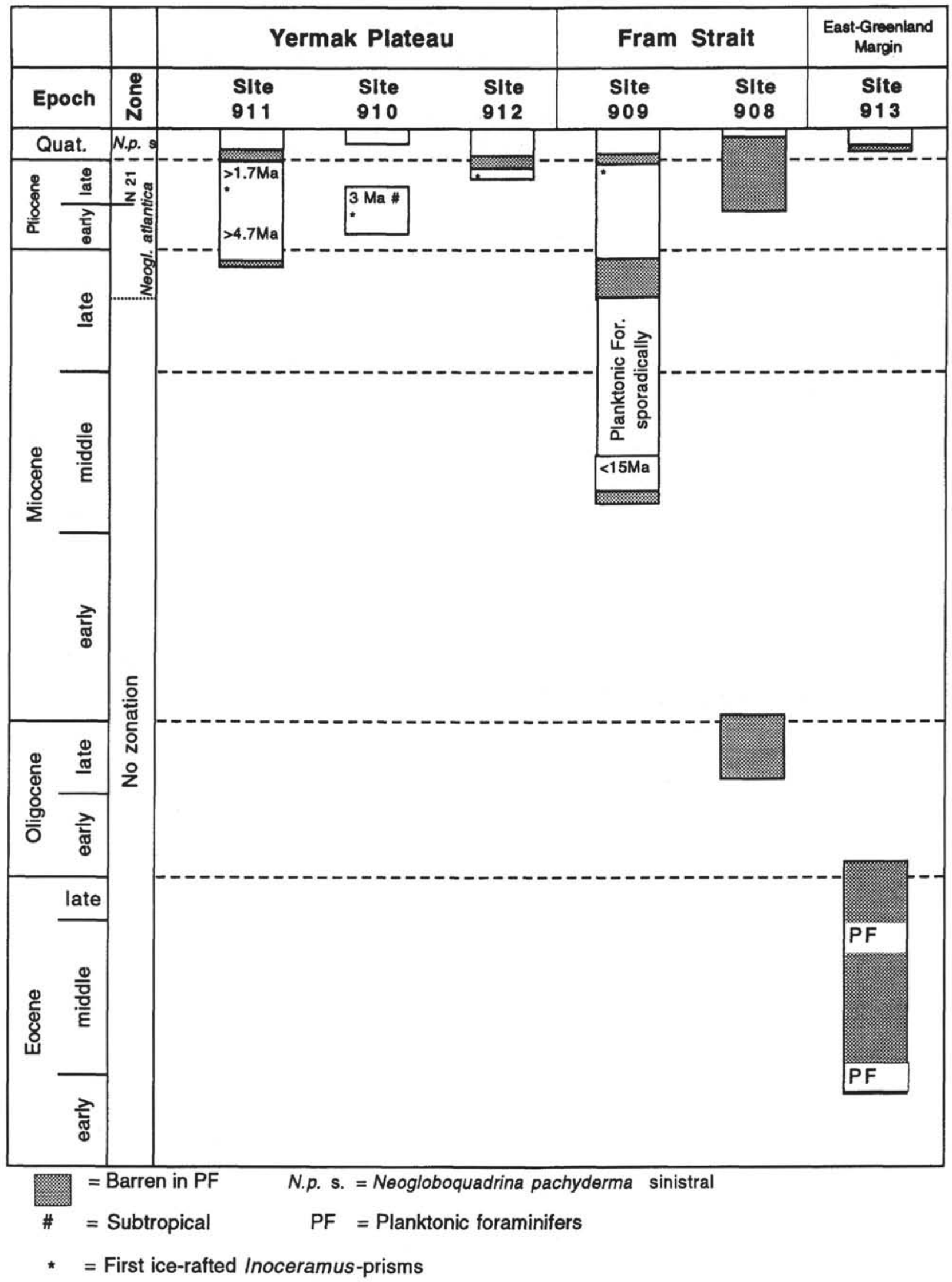

Figure 2. Summary of planktonic foraminifer zones recovered at Sites 908 through 913. 


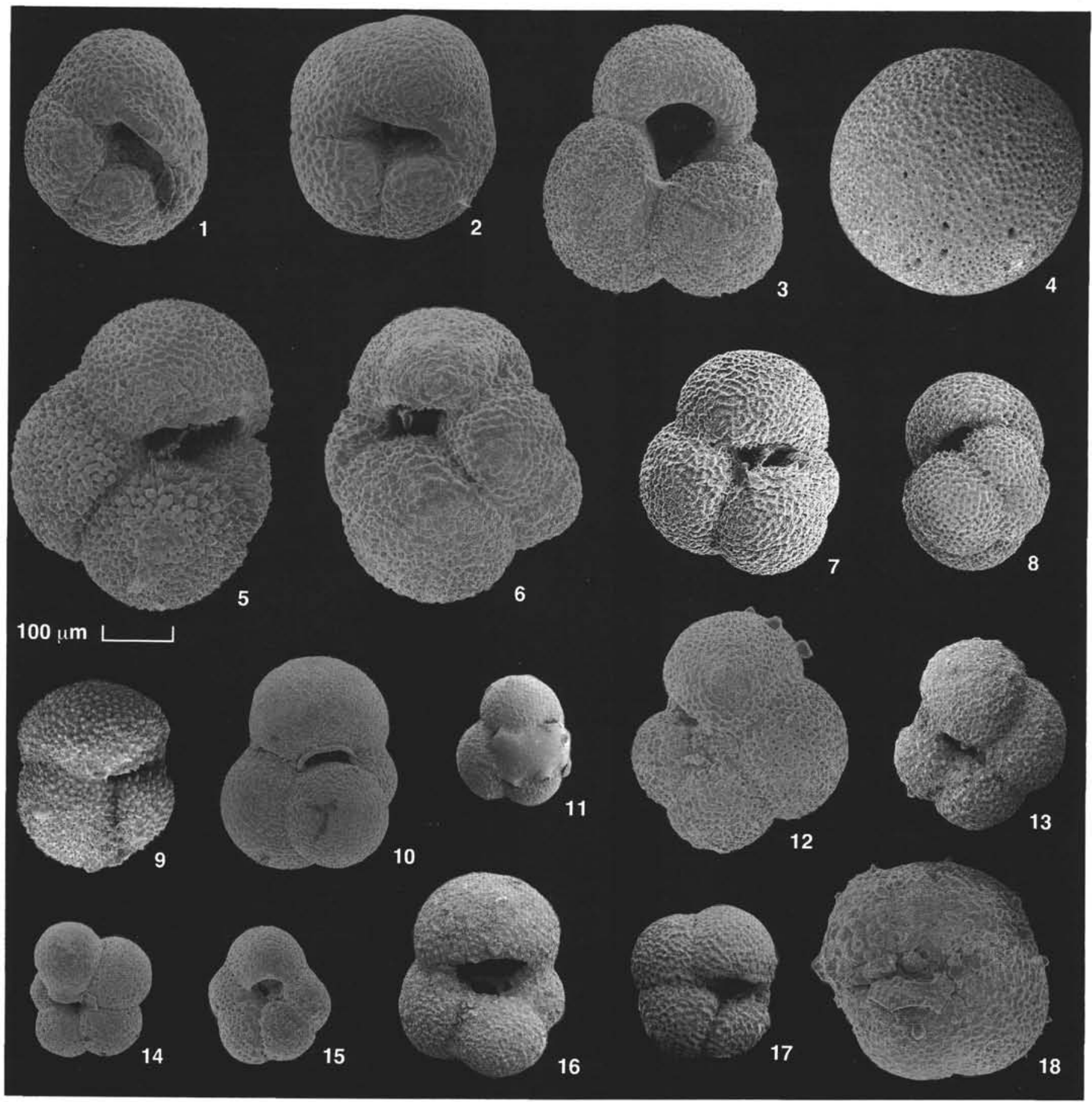

Plate 1. 1-2. Neogloboquadrina pachyderma (Ehrenberg), sinistral, Sample 151-910A-2H-CC, 20-22 cm, Quaternary. 3. Globigerina bulloides Orbigny, Sample 151-909C-103R-2, 3-7 cm, middle Miocene. 4. Orbulina universa Orbigny, Sample 151-911A-16X-3, 116-120 cm, Quaternary. 5-6. Neogloboquadrina asanoi (Maiyasaito and Sato), Sample 151-909C-10R-5, 43-47 cm, upper Pliocene. 7-8. Neogloboquadrina atlantica (Berggren) sinistral, 7. Sample 151910C-20R-CC, upper Pliocene. 8. Sample 151-910C-20R-2, 69-72 cm, upper Pliocene. 9. Globoconella cf. inflata (Orbigny), Sample 151-911A-16X-3, 116$120 \mathrm{~cm}$, Quaternary. 10. Globigerinita glutinata (Egger), Sample 151-909C-32R-1, 28-32 cm, upper Pliocene. 11. Globigerinita glutinata (Egger), forma ambitacrena (Loeblich and Tappan), Sample 151-909C-103R-2, 3-7 cm, Miocene. 12-13. Paragloborotalia continuosa (Blow), Sample 151-911A-53X-5, 113-117 $\mathrm{cm}$, Miocene. 14-15. Turborotalia quinqueloba (Natland), Sample 151-909C-103R-2, 3-7 cm, Miocene. 16. Globigerina praebulloides Blow, Sample 151911 A-53X-5, 113-117 cm, Miocene. 17. Paragloborotalia nana (Bolli), Sample 151-911A-53X-5, 113-117 cm, Miocene. 18. Neogloboquadrina pachyderma (Ehrenberg), dextral, Sample 151-911A-53X-5, 113-117 cm, Miocene. 

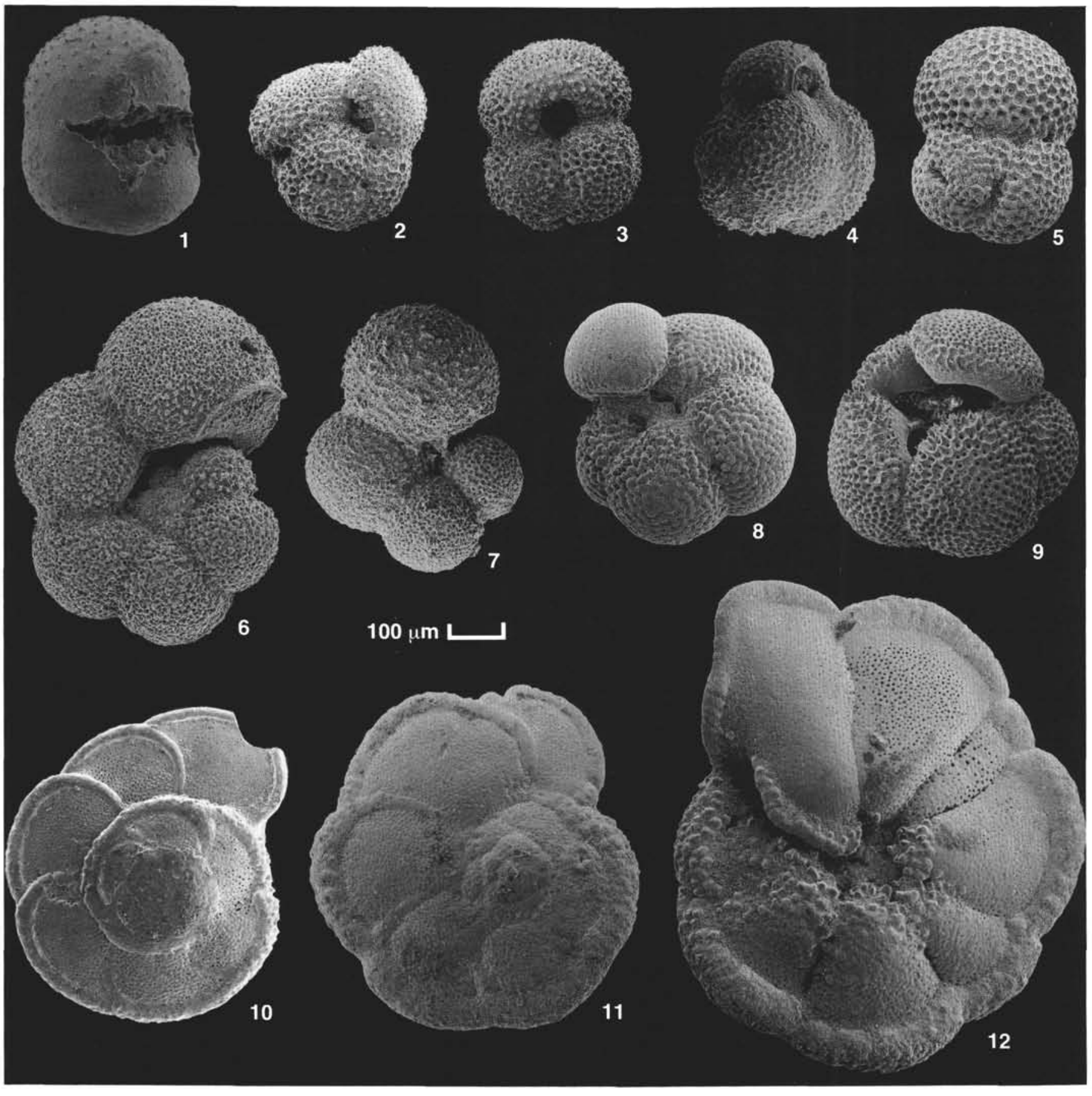

Plate 2. Subtropical upper Pliocene planktonic foraminifers at Site 910. 1. Sphaeroidinellopsis sp. juv., aff. S. paenedehiscens (Blow), Sample 151-910D-10X3, 74-76 cm. 2. Globigerinoides obliquus extremus Bolli and Bermudez, Sample 151-910D-16X-2, 74-76 cm. 3-4. Globigerinoides ruber (Orbigny), 3. Sample 151-910D-16X-2, 74-76 cm, 4. Sample 151-910D-15X-3, 74-76 cm. 5. Globigerinoides trilobus (Reuss), Sample 151-910D-10X-3, 74-76 cm. 6. Globigerinella aequilateralis (Brady), Sample 151-910D-13X-2, 74-76 cm. 7. Globigerinella siphonifera (Orbigny), Sample 151-910D-14X-2, 74-76 cm. 8. Neogloboquadrina dutertrei (Orbigny), Sample 151-910D-15X-3, 74-76 cm. 9. Dentoglobigerina altispira (Cushman and Jarvis), Sample 151-910D-16X-2, 74-76 cm. 10. Menardella limbata (Fornasini), Sample 151-910D-15X-3, 74-76 cm. 11-12. Menardella menardii (Parker, Jones, and Brady), 11. Sample 151-910D-15X$3,74-76 \mathrm{~cm}$. 12. Sample 151-910D-16X-2, 74-76 cm. 